\title{
ESCRITURAS E IMPRESOS EFÍMEROS DEL SIGLO XIX: ESPACIOS EN EL CONTINUUM DIACRÓNICO DE LA LENGUA
}

\author{
HERMINIA PROVENCIO GARRIGÓS \\ Universidad de Murcia \\ herminia@um.es \\ ORCID: 0000-0002-6145-5039
}

\section{RESUMEN}

Las escrituras e impresos efímeros del siglo XIX esconden fenómenos lingüísticos (cambios, innovaciones y reflexiones) que hay que rescatar para el estudio diacrónico de la lengua. A esta labor se dedica el monográfico número 9 de la revista Anuari de filología. Estudis de Lingüística. La presente contribución introductoria tiene tres objetivos: en primer lugar, exponer las características que se le atribuyen a lo efímero en el ámbito lingüístico; en segundo lugar, dar a conocer las marquillas cigarreras cubanas como fuente documental para el estudio de la lengua española de la época decimonónica; y en tercer lugar, presentar los cinco artículos que integran la sección monográfica, que, aunque diversos en las temáticas lingüísticas que analizan (morfosintaxis histórica, tradicionalidad discursiva, traducción, historia del léxico, modelos lingüísticos, evidencialidad, subjetivación), convergen en el uso de escrituras e impresos efímeros redactados durante el siglo XIX (cartas, prensa, dietarios...).

PALABRAS CLAVE: impresos y textos efímeros, siglo XIX, marquillas cigarreras cubanas, cartas, prensa, dietarios, diacrónica, español, catalán.

\section{WRITNGS AND EPHEMERAL PRINTS OF THE 19TH CENTURY: SPACES IN THE DIACHRONIC CONTINUUM OF THE LANGUAGE}

\section{ABSTRACT}

The ephemeral writings and prints of the $19^{\text {th }}$ century hide linguistic phenomena (changes, innovations and reflections) that must be rescued for the diachronic study of language. The monograph number 9 of the Anuari Journal of Philology is dedicated to the study of this topic. This introductory contribution has three objectives: firstly, to highlight the characteristics attributed to the ephemeral in the linguistic field; secondly, to make known the marquillas cigarreras cubanas as a documentary source for the study of the Spanish language of the nineteenth century; and thirdly, to present the five articles that make up the monographic section. These articles, although diverse in the linguistic themes that they discuss (historical morphosyntax, discursive traditionality, translation, lexicon history, linguistic models, evidentiality, subjectivation), share the use of ephemeral writings and prints written during the $19^{\text {th }}$ century (letters, press, diaries...) as a common object of study.

KEYWORDS: printed matter and ephemeral texts, $19^{\text {th }}$ century, marquillas cigarreras cubanas, letters, press, diaries, diachrony, Spanish, Catalan. 


\section{INTRODUCCIÓN: EL SIGLO XIX Y LO EFÍMERO}

El XIX es un siglo que concita expectación por ser, hasta hace relativamente poco tiempo, el gran ausente en los estudios lingüístico-históricos. Las aportaciones de este monográfico contribuyen a incrementar el caudal investigador de la lengua de ese período, crecido de forma muy significativa con publicaciones centradas en esa centuria (Melis, Flores y Bogard 2003; Ramírez Luengo 2012; Zamorano Aguilar 2012; Štrbáková 2013; Buzek y Šinková 2015a, 2015b; Melis y Flores 2015; Octavio de Toledo y Pons 2016; Carpi y García Jiménez 2017; Company y Flores 2017) y diacrónicas que la abarcan (Company 2006, 2009, 2014; Garachana 2017). ${ }^{1}$ La lectura de estas obras, entre otras muchas, nos transmite que el decimonónico es un tiempo complejo y dinámico en el continuum diacrónico de la lengua, pues en él surgen, se consolidan, se difunden o se concluyen cambios lingüísticos, innovaciones léxicas o reflexiones sobre la propia lengua que hacen que a un siglo cercano lo podamos considerar, desde una perspectiva diacrónica, lejano.

Es evidente que el XIX, como ocurre con otras épocas, va a tener ciertas especificidades que le vienen dadas, por ejemplo, por los avances técnicos y científicos; la independencia de las colonias españolas en América; la ocupación francesa; el costumbrismo con sus estrategias, formas y usos lingüísticos; la consolidación de la prensa como medio de comunicación y difusión; la publicación masiva de impresos efímeros (consecuencia de la mejora de los procesos de impresión), etcétera.

Este monográfico quiere sacar a la luz escrituras e impresos efímeros del siglo XIX como espacios de ese continuum diacrónico. La elección del adjetivo efímeros requiere concretar su significado y justificar su elección.

Desde sus primeras documentaciones efémera, efémero, efímera y efímero

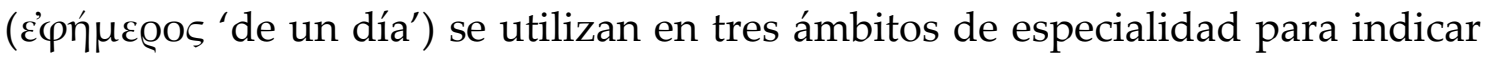
que algo tiene una vida o duración muy breve, por lo general, de un solo día: en patología (fiebre o calentura), en botánica (azucena, lirio) y en entomología (mariposa, gusano, cachipolla). Terreros y Pando en su Diccionario castellano con las voces de ciencias y artes... recoge las áreas de aplicación en las definiciones de efimera y efimero:

EFIMéRA, nombre que dán los Botánicos á muchas especies de flores, que, se abren al salir el Sol, y se secan del todo al ponerse: los Médicos á una calentura, que dura solo un dia: y los Naturalistas á unas mariposas blancas, y mui hermosas, que duran 24 horas.

EFIméRO, voz de la Historia Natural, gusano, de quien se afirma, que vive tres años á la orilla del agua, donde lo cojen los Pescadores para que les sirva de cebo: en él añaden, que se han observado hasta siete mil ojos, repartidos por todo su cuerpo: este gusano pasa á ninfa, y se hace insecto volante; y en cinco horas solas que vive como tal, extiende sus miembros, aparece joven, o nuevo, muda dos veces pellejo, produce su semilla, envejece,

\footnotetext{
${ }^{1}$ La bibliografía lingüística dedicada al período decimonónico es amplia. Remitimos a las referencias recogidas en las obras citadas.
} 
y muere. Aristóteles le describe como volante, y le llama efímero, porque dice que solo dura un dia, dándole el Filosofo 19 horas mas de vida de las que tiene.

Entre finales del siglo XVI y principios del XVII efímera y efímero comienzan a documentarse en sentido figurado y aplicarse como cualidad a cualquier cosa (s. f. 'Figuradamente se toma por duración breve y accidental' [DRAE, 1791: s. v. efímera]), tanto en España (1) como en América (2). Salvá (1846, s. v. efímero, ra, adj.) registra dos acepciones: 'lo que tiene una duración de un solo día' y 'pasajero, de corta duración', que se mantienen hasta hoy en el DLE (RAE-ASALE 2018 [2014]).

(1) A efímeras voluntades / bien es que las contraminen / mozárabes pretensiones, / que comienzan por los fines. (CDH, Juan de Salinas [1585-a1643]: Poesías. Henry Bonneville, Madrid, Castalia, 1987)

(2) Efímero fue, Leonor / en tu corazón mi amor. (CDH, Juan Ruiz de Alarcón [c1618]: Mudarse por mejorarse, México. Agustín Millares Carlo, México-Buenos Aires, Fondo de Cultura Económica, 1957)

La asociación del sustantivo ephemera a las obras impresas en papel se atribuye a John Lewis, quien en 1962 publicó Printed Ephemera, obra que agrupa impresos tan variados como indulgencias, proclamaciones, certificados, notificaciones oficiales, avisos, almanaques, horarios, hojas informativas, anuncios, programas, menús, etiquetas de vino, entradas, invitaciones (funeral, nacimiento, boda, cena, acto), billetes de circo, etiquetas y envolturas comerciales (tabaco, té, café, vino, perfume, productos farmacéuticos), etc. De acuerdo con Ramos Pérez (2003: 11), «[a] partir de ese momento [1962] surgen los estudios sobre lo que es ephemera, las colecciones que se incluyen dentro de sus límites y las mejores formas para su acceso y organización». Unos años más tarde, Lewis amplía la nómina de impresos que se incluyen bajo el término ephemera a las revistas, los cómics y la prensa (1976: 9). ${ }^{2}$

No obstante, John Grand-Carteret publicó en 1896 Vieux papiers, vieilles images con impresos y manuscritos semejantes a los que aparecerán años más tarde en la obra de Lewis. El autor francés les confiere «une place considérable

${ }^{2}$ Desde 1962 hasta ahora, la tipología de obras ephemera no ha variado sustancialmente. (Cf. Pemberton 1971; Trenc Ballester 1977; Richards 1977, 2000; Ramos Pérez 2003; McDowell 2012; Solé 2017; Rodríguez Leehmann y Bouzaglo 2018, entre otros).

Makepeace (1985: 10) no contempla las publicaciones periódicas: «Ephemera is the collective name given to material which carries a verbal or illustrative message and is produced either by printing or illustrative processes, but not in the standard book, pamphlet or periodical format». La propuesta de Mennessier (2005: 14) está en la misma línea: «Certes le périodique (et plus précisément le journal) s'apparente à l'éphémère dans le sens où tous les jours une nouvelle édition vient remplacer la précédente et la rend, en quelque sorte, périmée. Cependant la collection donne à l'ensemble sa valeur d'information et inscrit le périodique dans la durée, niant ainsi la fugacité de ses composants»; en cambio, para Belin (2015) «la frontière entre éphémère et périodique [...] devient poreuse», opinión en la que se insiste en Belin y Ferran (2016). 
dans l'histoire des transactions humaines» (1986: II) y los califica de «feuilles éphémères» (1896: 82).

Otras expresiones con las que se ha denominado a estos impresos o similares son «formas menos institucionales» (Rodríguez Leehmann y Bouzaglo 2018: 11), «pequeño impreso» (Trenc Ballester 1977, 2004: 80), «no libros» (Martínez González y Freire Santa Cruz 2018), «publicaciones menores» (Botrel 2016a, 2016b) o «menudencias» (Gomis Coloma 2015).

Sin entrar en las controversias acerca de los límites entre lo que son impresos efímeros y no efímeros, y sin pretensiones de exhaustividad, interesa destacar algunas de las definiciones y características que desde disciplinas como la Historia del Libro y del Impreso, la Tipografía, la Archivística, la Biblioteconomía o la Documentación les atribuyen a estas obras: ${ }^{3}$

Les vieux papiers, c'est ce que conservent soigneusement les délicats, les chercheurs, les curieux, tous ceux qui savent de quelle façon, à l'aide de ces petites choses, se reconstitue l'histoire ou se détruisent les légendes. (Grand-Carteret 1896: IX)

[D]ocuments which have been produced in connection with a particular event or item of current interest and are not intended to survive the topicality of their message. (Pemberton 1971: 6)

All this throw-away printing was a much more accurate mirror of the times than were the products of the book printer. [...] Printed ephemera is a term used for anything printed for a specific short-term purpose. (Lewis 1976: 9)

Above and beyond its immediate purpose, it expresses a fragment of social history, a reflection of the spirit of its time. [...] Broadly speaking, the word, ephemera, is used to denote the transient everyday items of paper -mostly printed- that are manufactured specifically to use and throw away. [...] Ephemera may be said to fall into three main groups: the truly transient (the ticket, the price tag, the coupon); the semi-durable (the playing card, the share certificate, the calendar), and the keep-it-forever (the mourning card, the commemorative souvenir) [...]. There can be no final opinion as to what constitutes ephemera and what does not. (Richards 1977: 9, 11-12)

A class of printed or near-print documentation which escapes the normal channels of publication, sale and bibliographical control. (Clinton 1981: 15)

Las características especificadas para los impresos efímeros deben, por una parte, reconducirse hacia los estudios lingüísticos ${ }^{4}$ - acostumbrados a manejar documentación efímera (pensemos, por ejemplo, en la Nodizia de Kesos, los billetes $^{5}$ o las relaciones de sucesos para la historia de la lengua española) - y,

${ }^{3}$ Las publicaciones que recogen los rasgos que se atribuyen a los impresos efímeros son numerosas (cf. Belin y Ferran 2016 y Solé 2017: 142-141).

${ }^{4}$ De esa forma, nos hacemos eco de las propuestas de investigación que Trenc Ballester (1977: 198), Ramos Pérez (2013: 13) o Belin y Ferran (2016) lanzaron a las humanidades. Reproducimos las palabras de Belin y Ferran: «Les réticences enfin des disciplines de lettres et sciences humaines à s'approprier les éphémères, en dépit des perspectives de recherches dont ils sont porteurs, dans des disciplines qui ont plutôt la culture du livre, du périodique, de l'archive, de l'auteur, de l'œuvre...» (2016: 5).

${ }^{5}$ Los billetes eran pequeñas misivas determinadas por la «escritura de la inmediatez», la «inmediatez de la entrega», el «secreto de la comunicación» (Castillo Gómez 2005: 852-853), «la 
por otra, girar en torno al significado etimológico del adjetivo efímero, que entendemos en sentido amplio, a fin de disipar los difusos límites entre lo que es o no efímero, tal y como prueban algunas de las opiniones mencionadas en líneas anteriores. ${ }^{6}$ A continuación, se detallan los rasgos que pueden atribuirse a $l o$ efímero:

- El mensaje que se comunica está vinculado con noticias, acontecimientos o hechos que suceden en un tiempo y lugar determinados, en otras palabras, es inmediato, puntual y efectivo para una época.

- La utilidad, vigencia o actualidad del mensaje suele ser breve e inmediata.

- Contienen ilustraciones y/o textos de extensión variable.

- Los aspectos que tratan, o para los que fueron creados, son muy diversos: políticos, comerciales, literarios, culturales, sociales, personales, de la vida cotidiana, etc.

- Los textos incluidos documentan la lengua de una época y suelen aproximarse al "polo concepcional de la inmediatez comunicativa» (Oesterreicher 2004: 734) con rasgos de oralidad del momento en el que fueron escritos.

- La escritura es manuscrita o impresa.

- El emisor y el receptor pueden ser individuales o colectivos, conocidos o desconocidos, etc.

- Son heterogéneos en cuanto a su formato.

- El material en el que se escribe o imprime suele ser de menor calidad que el que se utiliza para el libro impreso.

- Circulan en espacios públicos y privados de la vida cotidiana.

- La publicación puede ser ocasional o seriada.

- La conservación de la obra efímera va a depender de la finalidad y del valor que tenga para el receptor.

Los aspectos citados no deben concebirse en términos de exclusividad, es decir, como cualidades necesarias y suficientes compartidas por todas las escrituras, textos o impresos efímeros de épocas pretéritas. Así, los artículos de este monográfico utilizan como documentación escrituras e impresos (cartas, prensa, dietarios personales) en los que convergen algunos de los rasgos destacados en las líneas precedentes, que, como dijo Grand-Carteret (1986: IX), nos ayudan a reconstruir la historia, en este caso, de la lengua del siglo XIX, entendida como un continuum dentro de una diacronía.

Antes de presentar las contribuciones que conforman la sección monográfica, queremos dedicar un espacio a un corpus de obras impresas en

fragilidad de los soportes utilizados para escribirlos» y la «brevedad del mensaje» (Castillo Gómez 2013: 26-29).

${ }^{6}$ Para la consideración de las publicaciones periódicas como efímeras, consúltese la nota 2. 
América - tipificadas de efímeras en la bibliografía (Ramos Pérez 2013: 12) - y evidenciar que son una fuente documental para la investigación de la lengua española del siglo XIX, nos referimos a las marquillas cigarreras cubanas.

\section{UN LEGADO PARA LA LENGUA ESPAÑOLA DEL XIX: LAS MARQUILLAS CIGARRERAS CUBANAS}

Las marquillas cigarreras, llamadas también tabaqueras, son el papel litografiado que envolvía y adornaba los mazos de cigarros elaborados en la isla de Cuba durante el siglo XIX. Estas litografías tuvieron su época de esplendor entre los años 1860 y 1890; por tanto, pueden considerarse un discurso lingüística e históricamente cerrado que hay que interpretar en su contexto.

Uno de los mayores atractivos de las marquillas fue ser cromos coleccionables de gran colorido, de ahí que se enmarquen en un contexto divulgativo, que comparten con las cromolitografías incluidas en otros productos comerciales, por ejemplo, las cajas de cerillas. En la imagen 1 hay dos niños portando un mazo de cigarros envuelto en una marquilla.

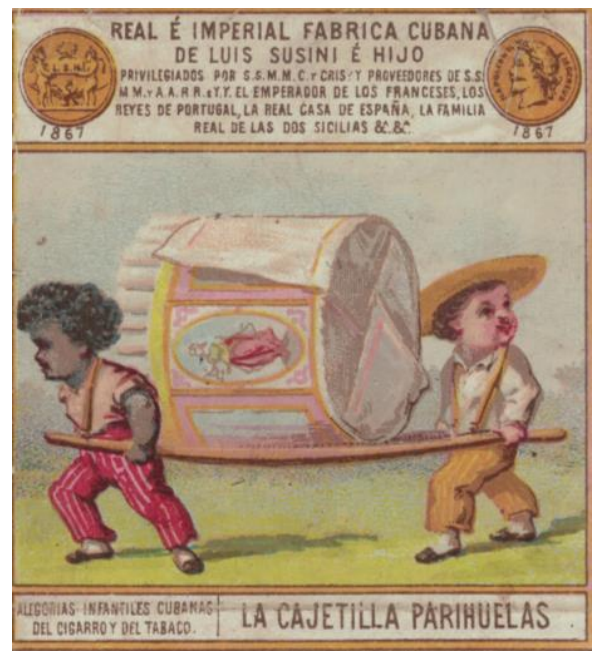

Imagen 1: Marquilla «La cajetilla parihuelas»

(Fuente: Colección particular de Lucía

Provencio. Reproducción autorizada) ${ }^{8}$

El tamaño de las marquillas cubanas oscila entre 12 centímetros de ancho por 8,5 de alto (De Juan 1974: 33). Su diseño tiene tres partes claramente diferenciadas, que ilustramos con la imagen 2: 1) la orla decorativa en los márgenes superior e izquierdo, por lo general, con motivos alegóricos o alusivos a la temática de la marquilla (cinco hombres en actitud irrisoria motivada por la

\footnotetext{
${ }^{7}$ El desarrollo de las técnicas de impresión de las artes gráficas en la segunda mitad del siglo XIX auspició la publicación de gran número de marquillas en Cuba.

${ }^{8}$ La reproducción de todas las marquillas de la colección particular que aparecen en este artículo ha sido autorizada por Lucía Provencio; en adelante, se citará la fuente como sigue: Colección particular.
} 
lluvia); ${ }^{9}$ 2) el emblema, en el margen derecho, con los datos distintivos de la fábrica de tabaco (la figura de una mujer, el nombre de la fábrica de tabaco: Para Usted, Gran Manufactura de Cigarros de Eduardo Guilló, y la dirección: Calle de los Oficios, № 23. Habana), ${ }^{10}$ y 3) la escena, ocupando la parte central, donde se incluye la relación de medallas y premios concedidos a la fábrica (normalmente en las exposiciones universales celebradas en Europa), el nombre de la serie a la que pertenece la marquilla (Estación de las Lluvias en una Ciudad de los Trópicos), la imagen (dos hombres bajo la lluvia) y un pequeño texto alusivo o descriptivo que complementa la imagen («Precausion para no morir ahogado»).

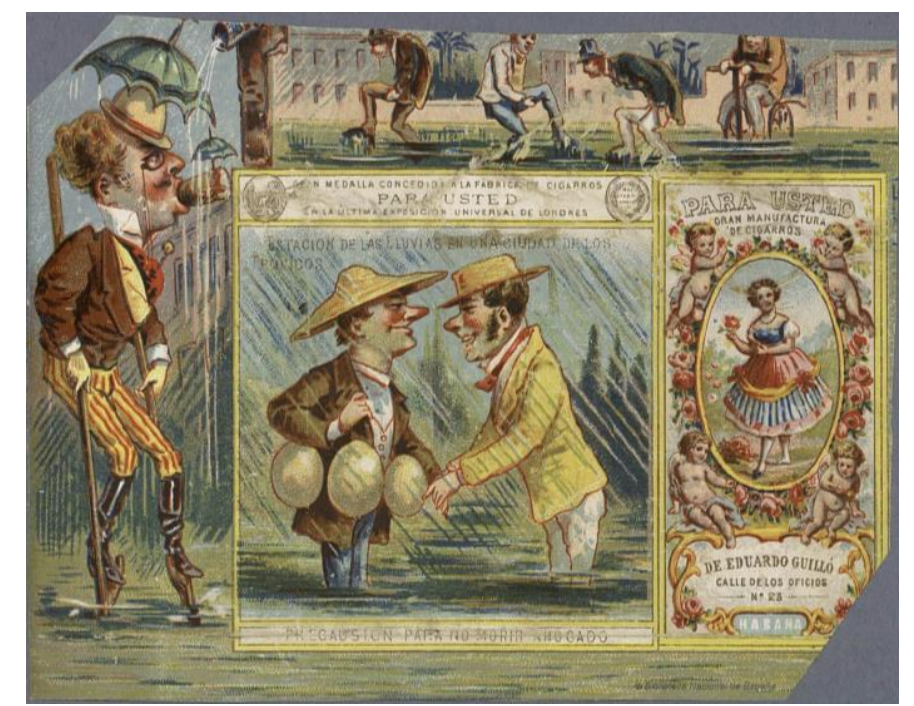

Imagen 2: «Precausion para no morir ahogado» de la serie Estación de Lluvias en una ciudad de los Trópicos. Colección de marquillas cigarreras cubanas de la Fábrica Para Usted (1860-1870). (Fuente: Biblioteca Digital Hispánica. Imagen perteneciente a los fondos de la Biblioteca Nacional de España, [(Eph. 70-J (142)])

La lista de temas y series protagonistas de las escenas de las marquillas es ingente: Alegorías infantiles Cubanas del Cigarro y el Tabaco (imagen 1), Alfabeto zoológico, Almanaque profético para el año 1866 (imagen 18), Baraja del Amor, Circo ecuestre, Colección cómica, Colección de mariposas, Cosas de la Habana, Costumbres cubanas, Don Quijote, Fábulas de Samaniego, Galería literaria, Galería mitológica, Muestras de azúcar de mi ingenio, Museo de las semejanzas, Publicaciones musicales, Tipos ingleses, Tipos del país, Uniformes del ejército español, Vida y Muerte de la Mulata (imagen 12), Virtudes y pecados,

9 Algunas marquillas de la colección particular citada en este trabajo no tienen orla; desconocemos con exactitud cuál es el motivo, pero es posible que el propietario original de las marquillas siguiera la costumbre de la época de recortar las orlas de los cromos para incluirlos en álbumes de colecciones (Botrel 2013: 21).

${ }^{10}$ Algunas fábricas incluyen también un eslogan, por ejemplo, «Los hechos me justificarán» (fábrica La Honradez) y «De lo bueno lo mejor» (fábrica Llaguno y Compañía). 
Vistas de la exposición de París de 1867, Voluntarios españoles de Cuba, Una visita a la fábrica la Honradez y un largo etcétera. ${ }^{11}$

Hay numerosas marquillas que no forman parte de ninguna serie, entre ellas están las más populares, por contener escenas humorísticas, satíricas, burlescas y picarescas en contextos que recrean los gustos y aficiones de los habitantes de La Habana, ${ }^{12}$ por ejemplo, la lotería, las peleas de gallos, el teatro, los toros, los paseos, los baños, los cafés o el carnaval. ${ }^{13}$ En suma, acceder a estas cromolitografías es, de acuerdo con De Juan (1979: 9, 35), adentrarse en «una crónica de la sociedad de la época, [...] penetrar en un mundo, aparentemente alegre, voluntariamente frívolo, a menudo burlón y ciertamente revelador de una concepción social determinada». ${ }^{14}$

La publicación de las marquillas tuvo varios objetivos: promocionar las marcas de las fábricas de tabaco; divulgar temas históricos, culturales y costumbristas; informar de las noticias que acontecían en la isla y fuera de ella y, en definitiva, entretener, divertir e instruir (a veces, con intenciones moralizantes) a unos lectores que, en su mayor parte, eran nacionales. La concurrencia de estos propósitos motivó que las series más populares fueran dicharacheras, nada sutiles y rezumaran frescura e inmediatez (De Juan 1974: 61, 1977: 17), tanto en la ilustración como en el texto (Provencio, en prensa). Lapique explica algunas de las causas de los objetivos mencionados:

Estas etiquetas [...] llegaron a ser un eficaz elemento publicitario y de divulgación, a veces, más importante que los periódicos y revistas de la época, porque no sólo eran vistas por miles y miles de fumadores por cuyas manos pasaban, sino además porque, al graficarse la noticia, el hecho acaecido en Cuba o en el exterior se difundía más por la imagen que por la prensa escrita, ya que en la época no todos podían comprarla por su bajo poder adquisitivo y, sobre todo, porque la inmensa mayoría de la población no sabía leer ni escribir. (1999: 105)

\footnotetext{
${ }^{11}$ Núñez Jiménez (1989: 35-132) expone una lista detallada y comentada de las series disponibles en la Biblioteca Nacional José Martí de La Habana hasta 1989, y Ramos Pérez (2003: 142-147), de las de la Biblioteca Nacional de España (BNE) hasta 2003.

${ }^{12}$ Los acontecimientos históricos acaecidos en la isla de Cuba hicieron que en La Habana concurrieran personas de origen muy diverso; la bibliografía las nombra de varias formas, aquí utilizaremos las denominaciones genéricas: negros bozales (nacidos en África), negros criollos (nacidos en territorio americano); mulatos (hijos de negros y blancos); blancos criollos (nacidos en América) y peninsulares (nacidos en España). El adjetivo bozal también refería al africano que no hablaba español y, si lo hacía, era de forma muy deficiente; ladino, al africano que hablaba español, aunque con cierta dificultad, y criollo, al nacido en territorio americano, que, sin duda, hablaba español. Durante la segunda mitad del siglo XIX llegaron a Cuba muchos inmigrantes de origen oriental, sobre todo chinos, para trabajar en las fábricas de tabaco (Hazard 1928: 170-171). Aquellos años fueron, como escribe Moreno Fernández (2006: 89), «un auténtico hervidero sociolingüístico».

${ }^{13}$ Hazard (1928) y González del Valle (1947) recrean las costumbres habaneras más populares.

${ }^{14}$ Esta visión idílica no debe hacernos olvidar que las marquillas se enmarcan en una sociedad esclavista y racista (Andreo 2013: 197), aunque algunas de ellas dan la impresión de que «la esclavitud fuera un estado de bienestar» (De Juan 1974: 20).
} 
La importancia de estas estampas o cromos ya fue reivindicada por Fernando Ortiz en 1940 como «un tesoro demopsicológico» del pueblo de Cuba, que todavía estaba por explorar. Se preguntaba «¿[q]uién lo estudiará?» (1999 [1940]: 453). El interrogante obtuvo respuesta unos años más tarde, sobre todo, a partir del último tercio del siglo $\mathrm{XX}$, período en el que estos pequeños impresos comenzaron a ser fuente documental y objeto de interés para la investigación en disciplinas y áreas de conocimiento diversas: Historia de América, Historia del Arte, Historia Cultural o Literatura. Andreo (1999a) y Andreo y Gullón (1997) resaltaron el papel de las marquillas como fuente historiográfica para el análisis de la realidad política y social cubana. Un foco de atención importante son los trabajos dedicados al estudio de las identidades nacionales, racializadas y de género reflejadas en las ilustraciones (Medrazo 1999; Fraunhar 2010; Andreo 1999b, 1999c, 2013; Méndez Gómez 2015). Desde las materias artísticas destacan las publicaciones de Lapique (1999) y De Juan (1974, 1977); esta última insiste en la idea de que las cromolitografías cubanas son un verdadero legado con gran valor documental, a pesar de «sus evidentes deficiencias desde el punto de vista estrictamente pictórico» (1974: 61). Desde la Historia del Arte, Sepúlveda (2015) investiga el tratamiento de la higiene social a través del humor racializado que muestran cinco marquillas. Calzadilla (2018) ha indagado en la utilidad patrimonial, documental y costumbrista de las marquillas desde la Iconología. Los estudios filológicos que promueven la investigación sobre estas pequeñas obras de arte lo hacen desde las perspectivas histórico-cultural y literaria, concentrando su interés, por ejemplo, en la proyección del mito yoruba de la diosa Ochún en la mulata (Cámara 2003), en el humor y la burla que reflejan las imágenes (Lugo Ortiz 2012; Aramburu 2010) o en el papel que desempeñan en la conformación literaria de la mulata (Kutzinsky 1993).

La revista Herencia Cultural Cubana publicó en 2013 dos números de carácter divulgativo dedicados al mundo del tabaco y a la litografía en Cuba, en los que Giménez Caballero y Sánchez Bustamante escribieron sendos artículos sobre las marquillas cigarreras con abundancia de ilustraciones.

En este breve recorrido bibliográfico, realizado sin intención de ser exhaustivo, no pueden faltar tres referencias: las dos obras que el espeleólogo y geógrafo cubano Antonio Núñez Jiménez dedicó a las 3932 marquillas depositadas en las Biblioteca Nacional José Martí: Cuba en las marquillas cigarreras del siglo XIX (1985) y Marquillas cigarreras cubanas (1989). Son las primeras publicaciones dedicadas en su totalidad a esta temática, las más divulgativas y descriptivas y las que pusieron al alcance del lector todo un mundo discursivo prácticamente inexplorado. La tercera referencia es el catálogo Ephemera. La vida sobre papel. Colección de la Biblioteca Nacional (2003), elaborado y redactado por Rosario Ramos Pérez (en colaboración con Rosario Pérez Rosado) con motivo de 
la exposición que tuvo lugar entre octubre de 2003 y enero de 2004 en la BNE. ${ }^{15}$ En síntesis, y glosando las palabras de Luis Racionero en la presentación de Ephemera. La vida sobre papel, estas pequeñas obras (las marquillas) hacen «perdurable» lo que nació para ser «efímero».

Hasta donde la búsqueda bibliográfica ha podido confirmar, las marquillas cigarreras no han sido utilizadas para el estudio de la lengua española del siglo XIX en Cuba. Demandan una mirada interdisciplinar en la que la lingüística histórica debe tener cabida (Provencio, en prensa). Obviamente, no todas las marquillas son relevantes para la investigación filológica. Las que despiertan mayor interés son las que por su ilustración (texto e imagen) permiten hacer un análisis multimodal - en el que el texto funciona como glosa de la imagen - y aquellas en las que se rastrean variaciones dialectales y sociolectales, consecuencia, entre otras cosas, de su singularidad, verbigracia, ser ágiles, ingeniosas $\mathrm{y}$, sin duda, muy populares entre los habitantes de La Habana (Provencio, en prensa). ${ }^{16}$ En este lugar, se presentan algunas pinceladas de los hechos lingüísticos reflejados en las marquillas - evidencias del uso del español en Cuba en el siglo XIX (§2.1) - , y sobre la intertextualidad y tradición discursiva que muestran (§2.2).

\subsection{Evidencias lingüísticas}

Las marquillas no fueron ajenas a las preocupaciones y comentarios ortográficos y gramaticales que afloraban en el siglo XIX. El ejemplo prototípico nos lo da uno de los rasgos fonéticos compartido por las variedades americanas y meridionales del español, nos referimos a la neutralización de consonantes líquidas (/l/, /r/), proyectada en la escritura, tal y como ilustra el texto de la escena de la imagen 3 en la que el maestro corrige lo que el alumno ha escrito en la pizarra («Los sordados») diciéndole: «Muchacho, sordado se escribe con L».

${ }^{15}$ El catálogo se completa con la colección Ephemera de la Biblioteca Digital Hispánica (BNE), que atesora gran número de marquillas cigarreras cubanas. Las 380 marquillas reproducidas en Núñez Jiménez $(1985,1989)$ y las de la colección Ephemera de la BNE son el corpus utilizado en la mayor parte de las investigaciones y trabajos divulgativos dedicados a su estudio.

${ }^{16}$ Las causas de las variaciones dialectales y sociolectales han sido expuestas profusamente en la bibliografía sobre el español de las Antillas. Remito, entre otros muchos, a Aleza Izquierdo y Enguita Utrilla (2010), Castellanos y Castellanos (1992: 283-365), Domínguez Hernández (2007, 2012), Granda (1971), Isbăşescu (1968), López Morales (1980, 1992, 2018), Vaquero de Ramírez $(1996,2006)$ y a las referencias que en ellos se incluyen. 


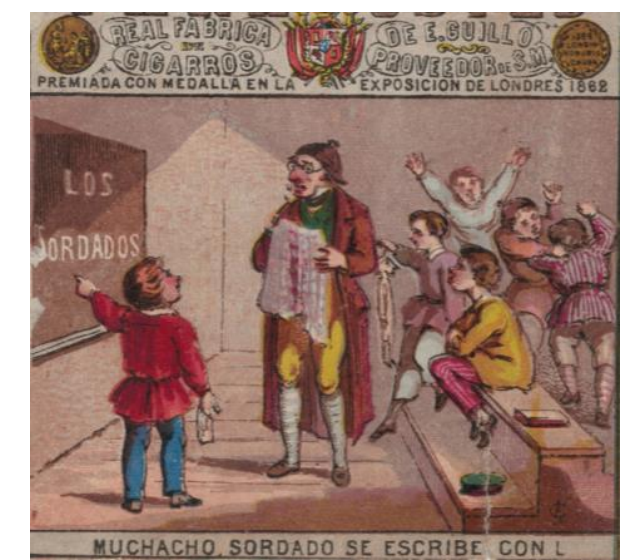

Imagen 3: Marquilla «Muchacho, sordado se escribe con L» (Fuente: Colección particular) ${ }^{17}$

Esta preocupación lingüística tiene su correlato en la prensa de la época; por ejemplo, la neutralización de la marquilla anterior («sordado») se reproduce en dos artículos del periódico El Moro Muza en los que se expresa sin ambages la crítica a los que defienden «la jerga» de «algunas repúblicas hispanoamericanas», como se advierte en los ejemplos (3) y (4):

(3) Se pone particular empeño en criticar lo que se comprende menos. Por ejemplo: el que no sabe ortografía le dice al que la sabe, que balde se escribe con $r$, parodiando al maestro de escuela que decía: "Muchacho! Sordado se escribe con ele." (El Moro Muza, periódico satírico, burlesco de Costumbres y Literatura, núm. 8, La Habana, 4/12/1959: 59, Hemeroteca digital de la Biblioteca Nacional de España) ${ }^{18}$

(4) [...], hay algunas repúblicas hispanoamericanas, donde se va convirtiendo la lengua de Cervantes en una jerga, y sin embargo, los que hablan esa jerga, llegan á creer formalmente, que conocen el idioma de Castilla mejor que los castellanos. De ahí proviene la frecuencia con que parodian al maestro de escuela que decía: "Muchacho! Sordado se escribe con ele." (El Moro Muza, periódico satírico, literario y artístico, núm. 12, La Habana, 19/1/1968: 106, Hemeroteca digital de la Biblioteca Nacional de España)

Las publicaciones costumbristas también se hicieron eco de las inquietudes lingüísticas; a este respecto, el artículo «El maestro de escuela» de José Agustín Millán (1852), incluido en Los cubanos pintados por sí mismos, prueba que saber gramática evita ciertas alteraciones fonéticas. El ejemplo (5) reproduce cuatro fragmentos de la conversación mantenida entre el maestro y sus discípulos (1852: 282-284), que resaltan la importancia de conocer la gramática española para escribir y hablar correctamente (5a), el uso del sufijo -encia (5b), el yeísmo (5c) y el ceceo (5d).

(5) a. Maestro.- [...] Veamos, Sr. Latranca; vamos á tratar del arte que nos enseña á hablar y á escribir correctamente ¿cuál es ese arte?

${ }^{17}$ Ignoramos si la marquilla pertenece a una serie; las indagaciones realizadas, hasta el momento, no arrojan información al respecto.

${ }^{18} \mathrm{El}$ ejemplo de (3) se incluye en la sección «El mundo al revés» del periódico, que recuerda a uno de los temas más recurrentes en las aleluyas (\$2.2). 
Discípulo. - La gramática.

Maestro. - [...] tenga vd. la bondad de decirnos si es posible escribir ó hablar sin saber gramática Es claro que no.... ¿no es así?

Discípulo.- Sí, señor.

b. Discípulo. - Por primera vez vieron el tabernáculo y conocieron la diferiencia.....

Maestro.- [...] Estoy ya cansado de repetir que no debe decirse: diferiencia, sino diferencia. Todos los acabados en encia [...] hacen encia.... Excepto paciencia....

c. Maestro.- [...] Sr. De Balandrá ¿cómo se escribe la palabra gallina? ¿con ll ó con y? Discípulo. - Con $l l$.

d. Maestro. - Y la palabra salchicha ¿se escribe con só con $z$ ?

Discípulo.- Con $s$.

Hay marquillas que reproducen usos de la lengua oral, pequeños fragmentos de una oralidad simulada (Mancera Rueda 2009), de una mímesis de lo hablado o simulaciones (Oesterreicher 1996: 332, 2004: 755-756) en los que «es el autor del texto, o sea, la conciencia lingüística del autor, la que selecciona ciertos rasgos lingüísticos considerados característicos de la lengua hablada» (Oesterreicher 1996: 332, 2004: 756). En su mayor parte, los «rasgos lingüísticos» seleccionados abren el camino para realizar inferencias irónicas (Bustos 1996: 363), humorísticas y satíricas sobre la sociedad habanera del XIX. En este punto, hay que precisar que no se sabe con seguridad quiénes fueron los autores de las ilustraciones y textos de las cromolitografías; según los datos recabados, la autoría hay que atribuirla a los ilustradores y escritores cubanos, españoles y extranjeros que publicaban en la prensa. En las marquillas a las que hemos tenidos acceso, solo hay constancia visual de la firma de un tal C. Anillo en la serie Vida y muerte de la mulata y de las iniciales C. A. en algunos cromos que reflejan escenas de La Habana; ${ }^{19}$ sin embargo, la semejanza entre algunas de las escenas y las caricaturas, que se exhiben en la prensa satírica de la época, da pie para pensar que un grupo de marquillas fueron obra del bilbaino Víctor Patricio Landaluze (cf. Sánchez Roig 1966: 35, Medrazo 1999: 6, Kutzinski 1993: 69). ${ }^{20}$

Tras este párrafo, se expone una muestra representativa de esa oralidad mimetizada en las marquillas y trasladada a las representaciones gráficas de

${ }^{19}$ La información sobre la autoría de la serie Vida y muerte de la mulata contrasta con la que Aramburu da (parafraseando a De Juan 1980: 26-27): «Sabemos que sus grabados fueron utilizados por las fábricas La Charanga de Villergas (la serie Vida y muerte de la mulata) y Para Usted (la serie Para Usted)» (2010: 12, nota 11). La atribución puede deberse a que la figura de Landaluze aparece entre los personajes que decoran la orla de la serie; no obstante, y hoy por hoy, no podemos afirmar ni negar con certeza absoluta ninguna de las dos atribuciones de autoría.

${ }^{20}$ La figura de Landaluze nos interesa porque, casi con total seguridad, es el autor de algunos de los textos que se incluyen en las marquillas. Batista (1965: 10) dijo de él que «nos da los personajes de la Cuba colonial» y De Juan (1974: 19), que «[s]u testimonio pictórico lo sitúa como el documentalista más rico y veraz de los tipos y las costumbres de la Isla», palabras que, aunque asociadas tradicionalmente a su obra pictórica y caricaturesca, bien pueden caracterizar el uso del español en un contexto espacio-temporal específico con personajes coloniales. 
rasgos fonéticos, hechos morfosintácticos e innovaciones léxicas. ${ }^{21}$ Como se verá en las escenas, muchos de los fenómenos lingüísticos están puestos en boca de mujeres y hombres mulatos y negros, que guardan semejanza con las imitaciones de las hablas de los negros (bozales y criollos) recogidas en los textos literarios de corte costumbrista desde finales de los años 30 del siglo XIX (López Morales 2018: 74, 121-123; Vaquero de Ramírez 2006: 193), pero no puede obviarse que estos fenómenos tienen, como escribe López Morales (2018: 79), «en el ámbito hispánico general una historia y una geografía muy conocidas». Se documentan, por ejemplo:

- La inestabilidad de las vocales átonas: «siño» por señor (imagen 5).

- La vocalización de consonante líquida implosiva: «goido» por gordo (imagen 8).

- La pérdida de las consonantes /d/,/r/y /s/implosivas o finales: «mitima» por me estimas (imagen 5); «uté» por usted, «servi» por servir(le) (imagen 6); «depué» por después, «comite» por comiste (imagen 7); «moca» por mosca, «raca» por rasca (imagen 10); «hace» por haced, «mimo» por mismo (imagen 11).

- La reducción del grupo consonántico / ks/ en /s/: «estrangero» por extranjero (ejemplos 7 y 8 e imágenes 14 y 15).

- Usos yeístas: «caye» por calle (imagen 4).

- Casos de seseo: «precausion» por precaución (imagen 2); «lejesisi...» por el ejercicio (imagen 11).

- Contracciones y reducciones fonéticas: «mitima» por me estimas (imagen 5); «té» por usted, «pa» por para (imagen 6); «salá» por salada (imagen 7); «camará» por camarada, «compae» por compadre (imagen 8); «soda» por soldados, «pasá» por pasado (imagen 11).

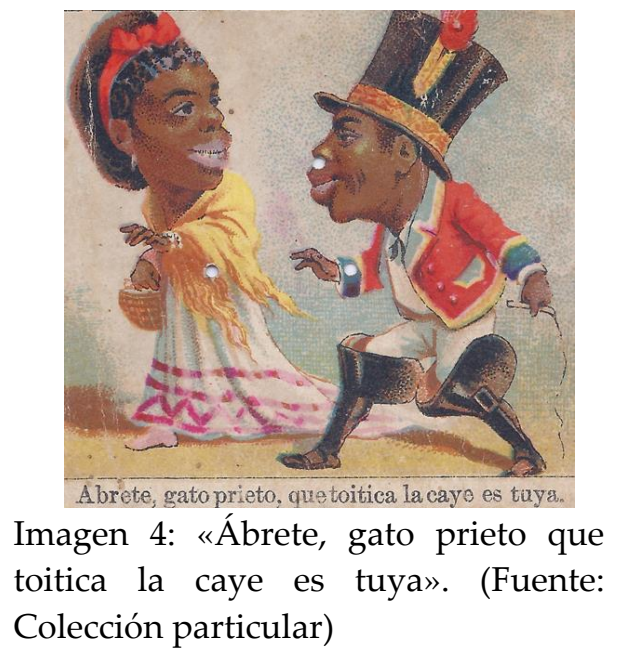

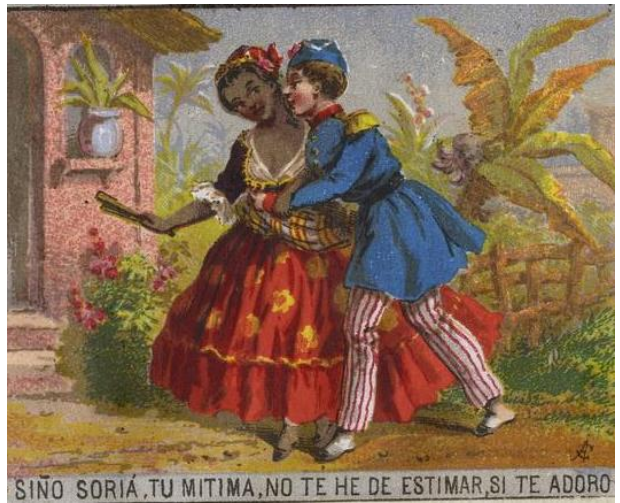

Imagen 5: «Siño Soriá. Tu mitima, no te he de estimar, si te adoro». (Fuente: Colección particular)

${ }^{21}$ La bibliografía sobre el español en Cuba y las circunstancias sociales y lingüísticas que coadyuvaron a su conformación es extensa (cfr. la bibliografía incluida en la nota 16). 


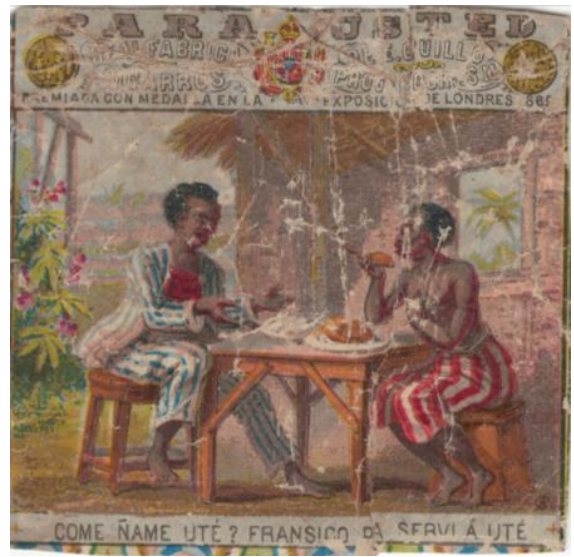

Imagen 6: «Come ñame té? Francisco pa servi a uté». (Fuente: Colección particular)

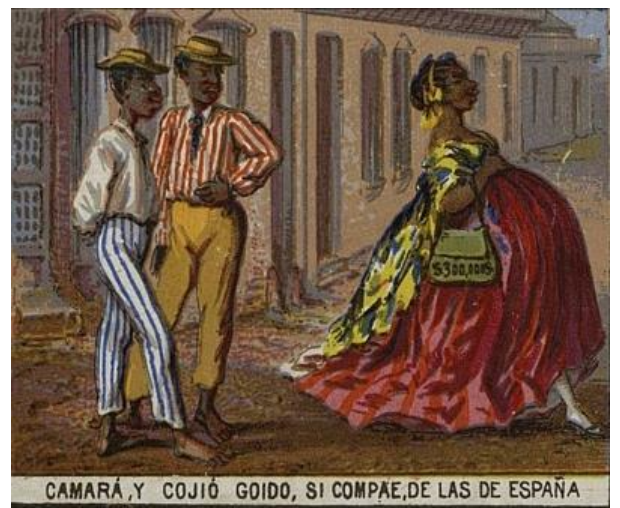

Imagen 8: «Camará, y cojió goido, si compae, de las de España». (Fuente: Colección particular)

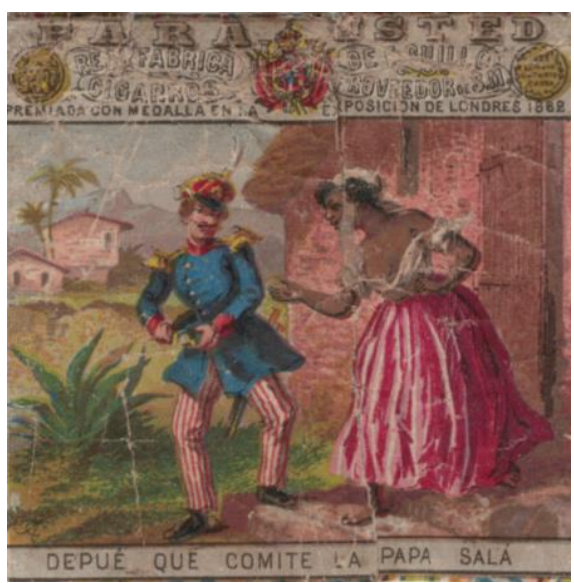

Imagen 7: «Depué que comite la papa salá». (Fuente: Colección particular)

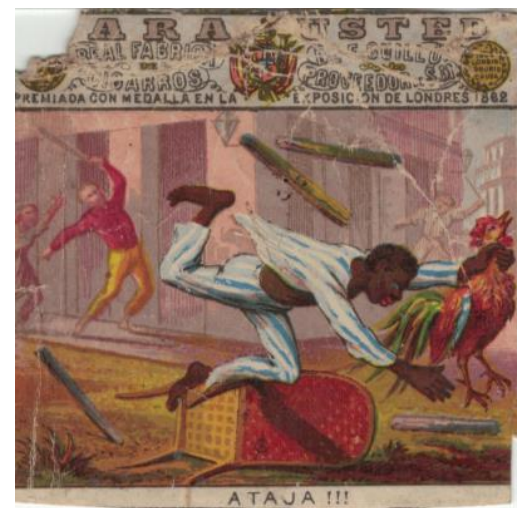

Imagen 9: «Atajá!!!». (Fuente: Colección particular)

Hay un conjunto de marquillas que bien podrían ser índices de las variaciones o vacilaciones operadas por los hablantes bozales y ladinos «que llevan la lengua dominante [el español] a sus máximos extremos de erosión y simplificación en todos los niveles» (Vaquero 2006: 193), así: «Ma que la moca. pica cuir'a quien raca» (Mas que la mosca pica, cuero [doy latigazos/castigo] a quien se rasca) ${ }^{22}$ (imagen 10) y «Soda hace lejesisi.... lo mimo que laño pasá» (Soldados haced el/lo ${ }^{23}$ ejercicio... lo mismo que el año pasado) (imagen 11).

${ }^{22}$ Castellanos y Castellanos (1992: 337) mencionan entre los ejemplos que utilizan para su investigación la palabra cuero: «Lo ingenio cuero na má», que traducen como «[se reciben] palizas)».

${ }^{23}$ Podría considerarse el uso del artículo lo como marca de pluralidad (Figueroa Arencibia 2007: 193-195, Vaquero 1996: 56). 


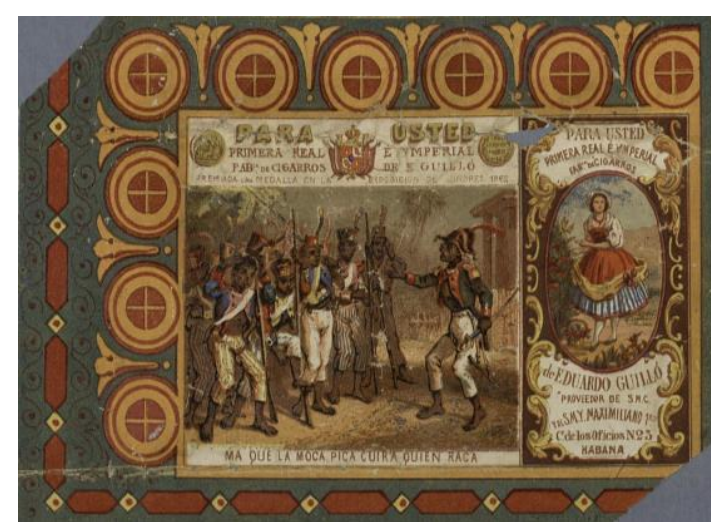

Imagen 10: «Ma que la moca. pica cuir'a quien raca». Colección de marquillas cigarreras cubanas de la Fábrica Para Usted (1860-1870). (Fuente: Biblioteca Digital Hispánica. Imagen perteneciente a los fondos de la Biblioteca Nacional de España [(Eph. 70-J (176)])

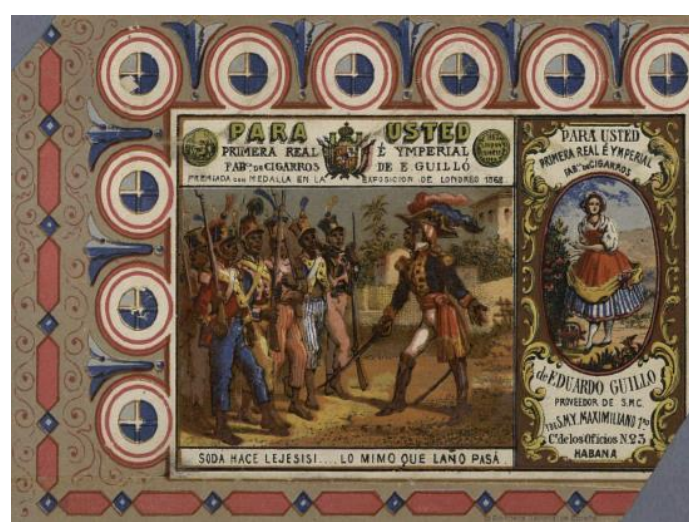

Imagen 11: «Soda hace lejesisi.... lo mimo que laño pasá». Colección de marquillas cigarreras cubanas de la Fábrica Para Usted (1860-1870). (Fuente: Biblioteca Digital Hispánica. Imagen perteneciente a los fondos de la Biblioteca Nacional de España [Eph. 70-J (177)])

Desde la morfosintaxis, se observan, por ejemplo, casos de supresión del artículo, como en «Camará, y cojió goido» (Camarada, y cogió el gordo) (imagen 8), o el uso del sufijo encadenado -itico/ -itica (RAE-ASALE 2009: 628-631), ${ }^{24}$ característico del español en Cuba (Domínguez Hernández 2012: 53), incluido en el texto de la marquilla «Ábrete, gato prieto que toitica la caye es tuya» (imagen $4)$, que tiene un valor apreciativo despectivo, respaldado por el significado del verbo «ábrete» ('marcharse de un lugar') y por «gato prieto» ('gato negro'). ${ }^{25}$

Con respecto al léxico, hay que mencionar ñame, palabra de origen africano (López Morales 2018: 85-102), incluida en el texto de la marquilla «Come ñame té? Francismo pa servi a uté» (imagen 6). Se juega con el doble sentido de ñame, es decir, como sustantivo ('tubérculo comestible') y como forma del verbo ñamar ('llamar') (Tristá Pérez y Cárdenas Molina 2016, s. v. ñamar). Este último sentido es el utilizado por uno de los protagonistas de la escena, quien a la pregunta «Come ñame té?» contesta: «Francisco pa servi a uté».

El doble sentido también se deja entrever en «Camará, y cojió goido» (imagen 8). La figura de la mujer negra embarazada -se supone que de un hombre blanco- y con un bolso, que lleva dibujada la cifra $\$ 300.000 \$$ pesos, hace que «goido» se interprete ya como el premio de la lotería, ${ }^{26}$ ya como el embarazo deseado para mejorar su estatus económico y social.

${ }^{24}$ Fenómeno morfológico frecuente en la documentación americana (Company 2012: 274-275, Ramírez Luengo 2007: 70-71).

25 Constantino Suárez incluye abrirse en su Vocabulario Cubano (1921) como vulgarismo: ‘Marcharse de un lugar con disimulo y precipitación. Es sinónimo de correrse y rajarse, en el mismo vulgar lenguaje. Tiene la acepción castellana'.

${ }^{26}$ La lotería era una de las grandes aficiones que había en La Habana en la segunda mitad del siglo XIX. Hazard llega a escribir: «Puede afirmarse que la lotería es la maldición de los cubanos. Todos ellos, desde el de la clase más alta a la más baja, [...] todos, todos están igualmente interesados en jugar a la lotería, de acuerdo con sus medios y al tenor del dinero que creen 
Las marquillas también son prolijas en el uso de interjecciones, así, «jatajá!» (imagen 9), que Esteban Pichardo define como sigue:

En la Habana cuando un delincuente huye, se da el grito terrible de Atajá, que se prolonga en todas las calles de su fuga por donde le persiguen corriendo, mientras los vecinos arrojan sillas, tinas, barriles y otros obstáculos para detener o entorpecer la carrera del criminal. (1862, s. v. atajá)

La escena de la marquilla recrea a la perfección lo descrito por Pichardo, es decir, se observa a un hombre saltando los objetos que los vecinos le arrojan tras haber robado una gallina.

También es habitual el uso de la interjección despreciativa jsía! (Ortiz 1924, s. v. jsía!) con alargamiento «ii_Siaa!!» (imagen 12 de la serie Vida y muerte de la mulata). En la escena se ve a un calesero con un látigo en la mano diciéndole a una mujer mulata desaliñada y cuya belleza se ha marchitado: «¿Caridad, quieres mecha? ii_Siaa!!». Dicho esto, no hay que ignorar que en esta escena «mecha» puede ser un sustantivo o un verbo. Para el primero se considera que «mecha» es «la parte delgada con que termina un látigo» (Ortiz 1923, s. v. mecha) y para el segundo, la acción que Constantino Suárez (1921) define de forma tan peculiar: «indecente. La acción contra el sexto mandamiento, y hasta contra la naturaleza del hombre» (s. v. mechar). Las marquillas que integran la serie Vida y muerte de la mulata y el mito de la mulata, como 'modelo cognitivo idealizado' (Lakoff 1987), no dan lugar a dudas en la interpretación: mecha es verbo o sustantivo metonímico ('órgano sexual masculino') (Provencio, en prensa).

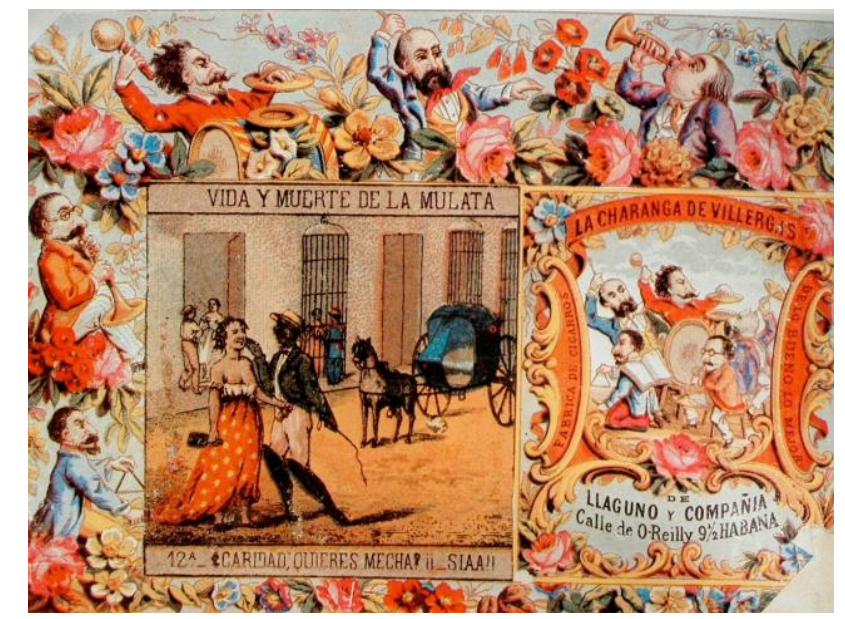

Imagen 12: «¿Caridad, quieres mecha? ii_Siaa!!». Marquilla n. 12 de la serie Vida y muerte de la Mulata. (Fuente: Núñez Jiménez 1985: 16)

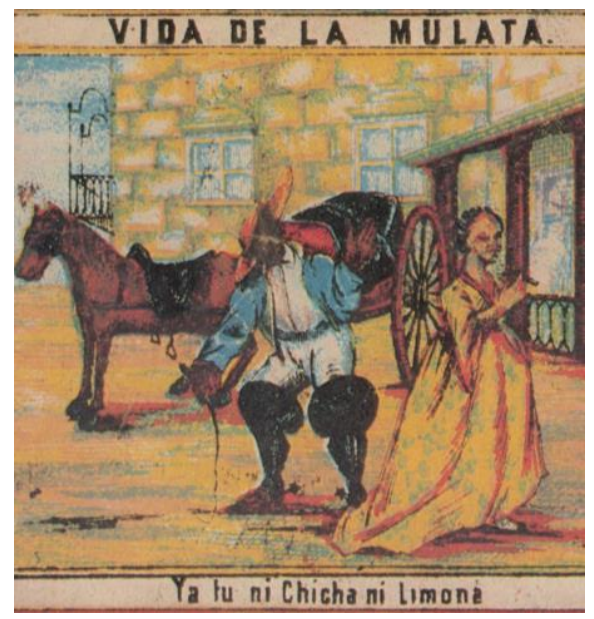

Imagen 13: "Ya tú ni Chicha ni Limoná». Serie Vida de la Mulata. (Fuente: Colección particular)

Concluimos la relación de evidencias lingüísticas con una de las más características del siglo XIX, nos referimos a la fraseología y, en particular, al uso

necesitar para dejar de trabajar, cometer alguna extravagancia o vivir en perenne fausto» (1928: 196-197). Evidentemente, las varias marquillas abordan esa temática. 
de la locución verbal «no ser alguien o algo ni chicha ni limonada». ${ }^{27}$ Los primeros registros que, hasta la fecha, hemos encontrado de la locución son de mediados del siglo XIX: el primero, en un texto publicado en 1849 en la sección «Variedades» del periódico El clamor público, en el que un suscriptor escribe sobre el uso de ni chicha ni limonada en una canción inventada por la «gente de color» que vivía en el barrio de extramuros de La Habana (6); y el segundo, en una marquilla tabaquera de la serie Vida de la mulata (imagen 13) en la que puede verse a una mujer mulata, de cierta edad y fumando tabaco, junto a un calesero que le dice "Ya tú ni Chicha ni Limoná», ${ }^{28}$ es decir, que ya no sirve para ser amante de ningún hombre (negro, mulato o blanco). ${ }^{29}$

(6) El año de 1828 se oyó por primera vez en un barrio estramuros de la Habana, en una choza de gente de color, una canción con el nombre de guanábana [...]. En 1828 apareció otra en el propio barrio con el de la limonada, inventada por los mismos, aludiendo á que se había concedido el título de cabo de ronda á un sujeto que, despues de haber admitido brindis de los negros en las bodegas, los perseguia y privaba sus reuniones, y por eso le cantaban que no era nada, ni chicha, ni limonada; lo que colocaban de estribillo, á todos los versos. (El clamor público. Periódico del Partido Liberal, Madrid, 26/1/1849, Madrid)

Esteban Pichardo registra la locución en la 3. a edición (1862) del Diccionario provincial casi-razonado de vozes cubanas: «Ni too, ni náa; ni chicha, ni limonáa. Refrán mui vulgar, significando la nulidad de alguna cosa; que no es, o no vale, o no sucedió nada absolutamente» (s. v. chicha). Montori y Céspedes (1916: 247) la incorpora en su lista de modismos usados por los campesinos para «expresa[r] la inutilidad de alguien o de alguna cosa».

\subsection{Evidencias de intertextualidad contemporánea y tradición discursiva}

En general, las marquillas no surgen ex nihilo, sino que están estrechamente vinculadas en su forma y contenido con las litografías incluidas en la prensa satírica de la época y con tradiciones discursivas. Las pesquisas que hemos realizado en las caricaturas publicadas en periódicos cubanos del XIX (Antón

\footnotetext{
${ }^{27}$ En el siglo XIX se dio el gran impulso a las recopilaciones y obras fraseológicas (Montoro del Arco 2012).

${ }^{28}$ En la sociedad colonial cubana del XIX la limonada era una bebida ligada a la clase social media y elevada y la chicha, a la clase social baja; así se infiere de la definición de Pichardo (1862): «Bebida agradable; aunque solo usada del bajo pueblo, compuesta de agua y azúcar quebrado, a la cual se echa mais tostado para precipitar la fermentación» (s. v. chicha).

${ }^{29}$ En el Álbum formado de cubiertas para cajillas de cigarrillos de varias marcas de la Habana. 1864 (Archivo General de Indias) hay una marquilla con la locución "Ya tú ni Chicha ni Limoná», aunque la ilustración y el nombre de la serie tienen pequeñas variaciones con respecto a los de la imagen 13. Las modificaciones eran frecuentes, porque las fábricas de tabaco imprimían las series más populares de forma reiterada, lo que favorecía algunas alteraciones en el nombre de la serie, la orla y la escena.
} 
Perulelo, Don Junípero, Juan Palomo y El Moro Muza) así lo testimonian; y lo mismo ocurre, como se verá más adelante, con la tradición discursiva.

La intertextualidad entre las marquillas y las caricaturas de la prensa es evidente, como ponen de manifiesto las escenas de las imágenes 14 y 15 y sus respectivas secuencias dialógicas en (7) y (8), ambas son muy similares. La caricatura se publicó el 5 de noviembre de 1862 en Don Junípero. Periódico satíricojocoso con abundancia de caricaturas, dirigido por Landaluze, lo que ayuda a colegir que son coetáneas y de ese autor. ${ }^{30}$

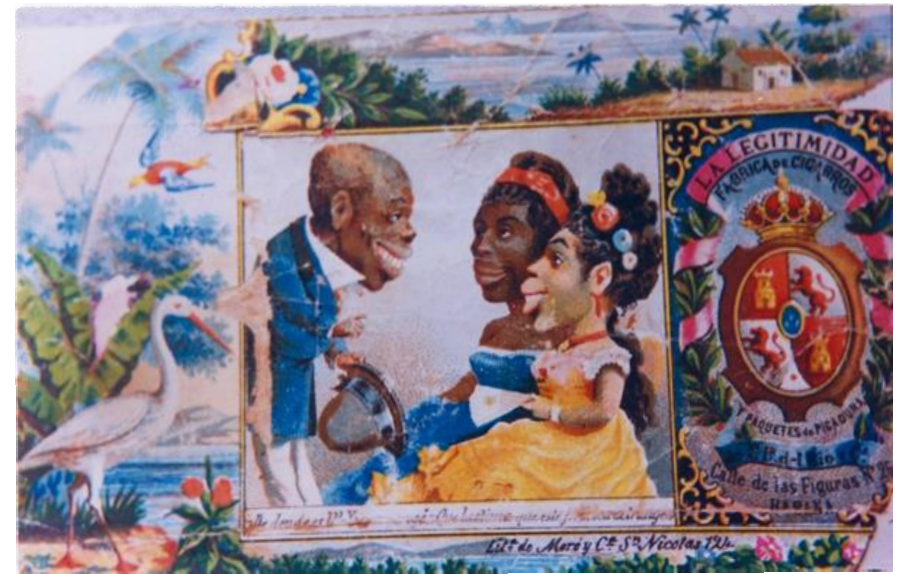

Imagen 14: Marquilla de la fábrica La Legitimidad. (Fuente: Colección particular)

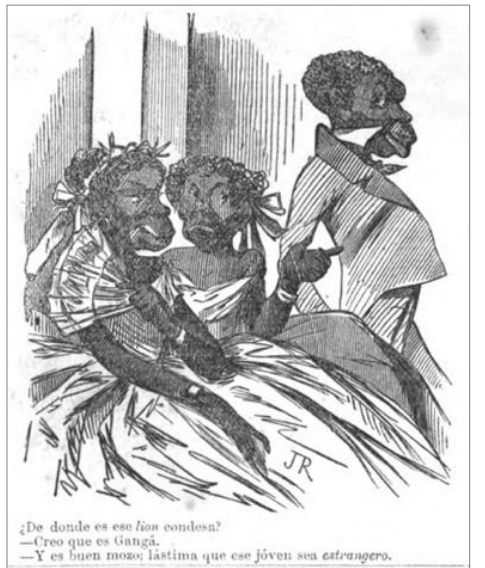

Imagen 15: Don Junípero, 5/10/1862, La Habana (Fuente: Don Junípero, v. 1, New York Public Library, Google)

(7) Secuencia dialógica de la imagen 14: — ¿De donde es V.? - Yo soy gongó. -Que lastima que este joven sea estranjero

(8) Secuencia dialógica de la imagen 15: ¿De donde es ese lion condesa? / -Creo que es Gangá. / -Y es buen mozo; lástima que ese joven sea estranjero.

Nuestra investigación también ha desvelado que las cromolitografías cigarreras cubanas se acogen a la tradición de los pliegos de cordel, las estampas y las aleluyas impresas en España, ${ }^{31}$ así como a las publicaciones efímeras impresas, por ejemplo, en Alemania, Francia y Austria. ${ }^{32}$ Comparten la fragilidad

${ }^{30}$ Las conexiones entre la prensa y las marquillas son evidentes. De Juan $(1974: 39,61 ; 1977: 17)$ opina que el vínculo es debido a la actualidad del tema tratado y a la agilidad que requiere el medio de publicación; Lapique (1999: 105) llega a aseverar que la prensa es la fuente directa para las marquillas y Mégevand (2018: 146) habla de «porosidad de género» y afirma que «[no] hay compartimentos estancos entre la prensa y las marquillas». Recientemente, Padilla (2019: 160) ha dicho que el origen de las viñetas cómicas de los periódicos se encuentra en la prensa americana de finales del siglo XIX.

${ }^{31}$ La aleluya es un pliego de papel suelto impreso, que incluye una serie de escenas en viñetas o estampas (por lo general, 48) sobre una temática específica y debajo de cada viñeta se hallan versos que aluden a la temática de la escena.

${ }^{32}$ Entre los artistas que desarrollaron su labor litográfica durante la segunda mitad del siglo XIX en Cuba había europeos - el francés Eduardo Laplante o el español, ya citado, Landaluze, entre otros (cf. De Juan 1974: 11-25) -, que debían conocer las publicaciones populares que se 
del material, la presencia de texto e ilustraciones, la variedad de temas tratados y el carácter popular. Rueda Ramírez recoge una relación de impresos efímeros «de vida limitada» y «de más larga duración» que salían de las imprentas andaluzas, extrapolables a las de otras ciudades de España (Madrid, Barcelona o Valencia):

Junto a las novelas y comedias, los libros religiosos, tratados y disposiciones jurídicas, textos científicos y las obras dedicadas a la historia, la música, la literatura etc., las imprentas andaluzas en el Siglo de Oro publicaron otro material, de carácter práctico, menor volumen y fugaz existencia: carteles, almanaques, relaciones de sucesos, estampas, tarjetas de visita o juegos de naipes, que satisfacían las necesidades de ocio, información y comunicación de los habitantes. (2014: 36)

Los asuntos que comparten las marquillas y las aleluyas son abundantes: escenas típicas, fiestas y costumbres, artes y oficios, juegos infantiles o personajes literarios; lo mismo ocurre con los nombres de las series: Abecedarios, Aventuras de Don Quijote, Colección de aves, Colecciones de trajes españoles, Corridas de toros, Costumbres de antaño y ogaño, Costumbres españolas, El ejército español, Escenas circenses, Fábulas de Esopo, Fábulas de Samaniego, Gil Blas de Santillana, Habitantes de las provincias de España, Habitantes de todos los países del mundo, Historia de Fausto y Margarita, Historia Sagrada, Juegos de la infancia, El mundo al revés, etcétera. ${ }^{33}$

Un grupo importante de marquillas, a la par que las aleluyas, tienen elementos lingüísticos que pueden explicarse por «tradicionalidad discursiva» (cf. Wintter-Froemel et alii 2015: 14-18), como los dísticos del género epigramático. Cuando Caro Baroja escribe sobre los dísticos de las aleluyas inspiradas en obras literarias españolas, afirma que «son, por lo común, de ramplonería espantosa y cuando hacen efecto es efecto humorístico» (1990: 502). Desde una perspectiva más funcional, Ortiz García (2000: 161, 182) considera que desempeñan una función «secundaria, asociada a la imagen, nemotécnica, explicativa y, en parte, prescindible. [...] son los más fácilmente descifrables por el público iletrado o analfabeto [...], de fácil memorización y reproducibles oralmente de modo seguido». El texto incluido en muchas marquillas no podría calificar de «secundario» o «prescindible» (Provencio, en prensa).

Para ejemplificar lo dicho, hemos seleccionado la serie Antaño y Ogaño, publicada por la fábrica La Honradez, que tiene su análoga en la aleluya Costumbres de Antaño y de Ogaño. La imagen 16 muestra las dos marquillas número 1 de la serie Antaño y Ogaño y la imagen 17, las dos viñetas número 12 de la aleluya. Tanto los textos de las marquillas (9) como los de la aleluya (10) son

imprimían en Europa, por ejemplo, los Münchener Bilderbogen alemanes o los impresos franceses de la fábrica de Pellerin.

${ }^{33}$ Una amplia lista de aleluyas puede consultarse en el catálogo de la colección de aleluyas de la Fundación Joaquín Díaz, accesible en el Portal Fundación Joaquín Díaz de la Biblioteca Virtual Miguel de Cervantes (http://www.cervantesvirtual.com/portales/fundacion_joaquin_diaz). 
ilustrativos de los típicos pareados humorísticos que se escribían como consecuencia de la afición por el baile que existía en la época.
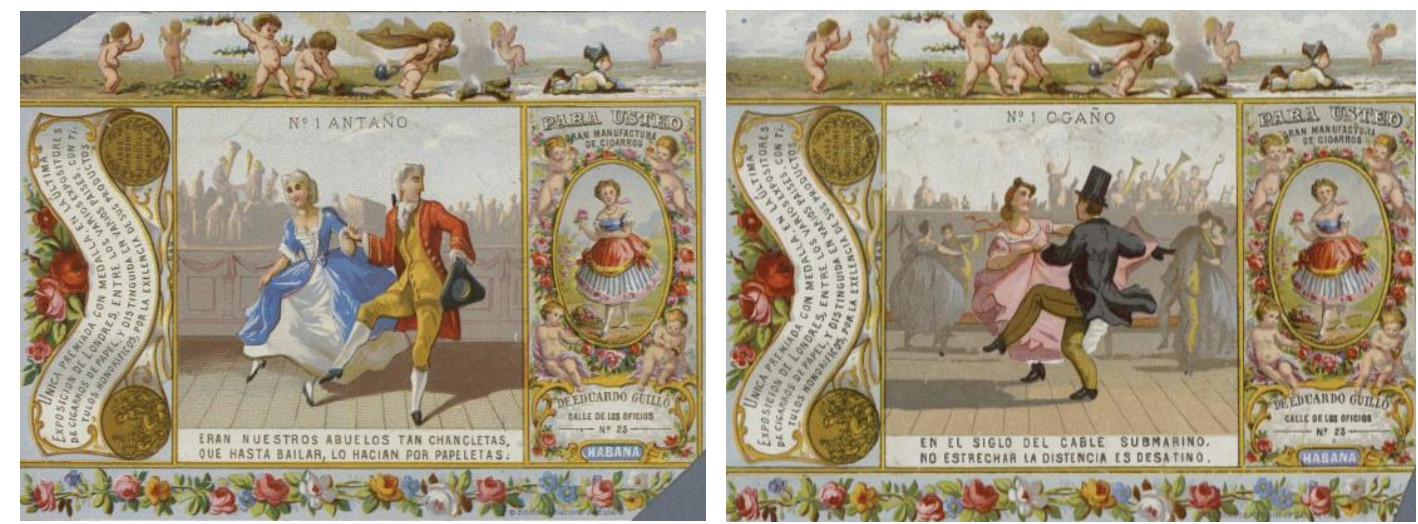

Imagen 16: Serie Antaño y Ogaño de la Colección de marquillas cigarreras cubanas de la Fábrica Para Usted (1860-1870). (Fuente: Biblioteca Digital Hispánica Imágenes pertenecientes a los fondos de la Biblioteca Nacional de España, [Eph. 70-J (57) /Eph. 70-J (60)])

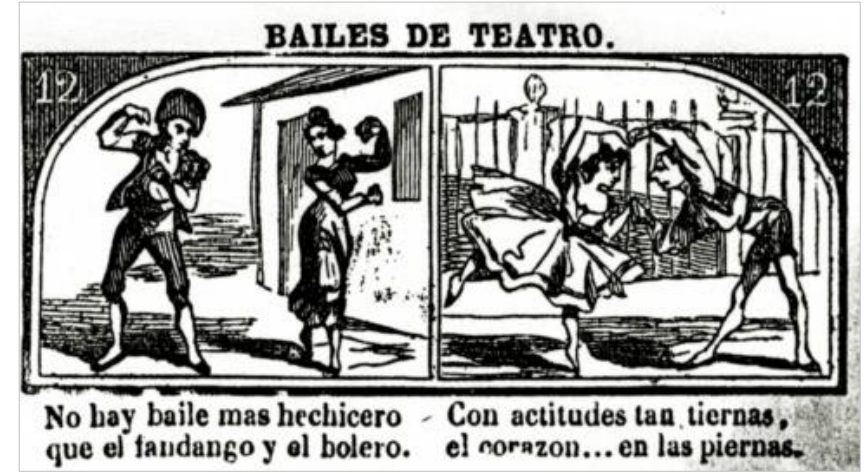

Imagen 17: Escena «Bailes de Teatro» de la Aleluya Costumbres de antaño y de ogaño, Madrid: Imprenta de Marés y compañía, (plazuela de la Cebada, 13), 1866. (Fuente: Portal Fundación Joaquín Díaz de la Biblioteca Virtual Miguel de Cervantes, http://www.cervantesvirtual.com/nd/ark:/59851/bmcbv990)

(9) N.․ 1 ANTAÑO: Eran nuestros abuelos tan chancletas, / Que hasta bailar, lo hacían por papeletas.

N. 2 OGAÑO: En el siglo del cable submarino, / No estrechar la distancia es desatino.

(10) BAILES DE TEATRO: 12. No hay baile más hechicero / que el fandango y el bolero. 12. Con actitudes tan tiernas, / El corazón... en las piernas.

Entre los dísticos más populares se encuentran los de las series dedicadas a los almanaques. En la marquilla correspondiente al mes de mayo de la serie Almanaque profético para el año 1866 de la fábrica La Honradez (imagen 18) se observan a dos soldados vomitando y a una mujer sosteniendo a uno de ellos; el pareado «De "La Honradez" fumarás o el vómito tendrás» mezcla la intención publicitaria de la fábrica con la burla e ironía hacia los soldados y lo que estos representan (cf. Aramburu 2010: 22). 


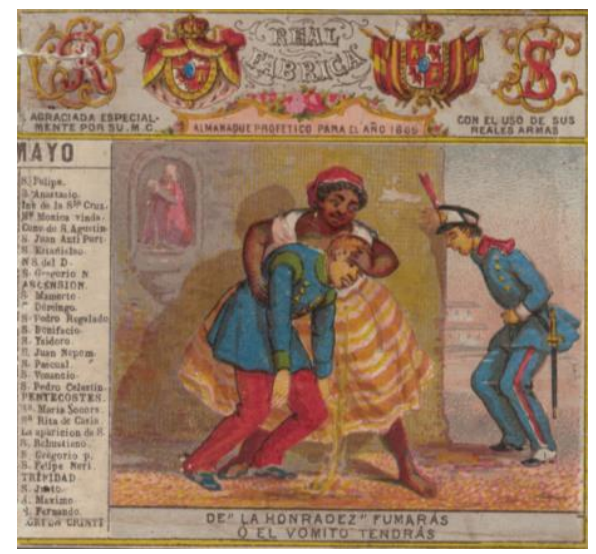

Imagen 18: «De "La Honradez" fumarás o el vómito tendrás». Serie Almanaque profético para el año 1866 (Fuente: Colección particular)

\section{UN LEGADO PARA LA LENGUA DEL SIGLO XIX: CARTAS, PRENSA, DIETARIOS...}

Ha llegado el momento del espacio dedicado a la presentación de otras escrituras e impresos efímeros (cartas, prensa...) depositarios de ideas y hechos lingüísticos que acontecieron, o bien en el siglo XIX, o bien se iniciaron en tiempos pasados, pero que se consolidaron en el decimonónico.

La disposición de los artículos responde a tres criterios: en primer lugar, si el objeto de estudio se centra exclusivamente en el siglo XIX o culmina en él; en segundo lugar, la mayor o menor condición de efímera de la documentación manejada (atendiendo a los rasgos descritos en §1) y, en tercer lugar, la fecha de publicación de los textos.

Las contribuciones se inician con el estudio «Sintaxis de la prosa del instante: la lengua de una tradición efímera en los albores del siglo XIX», escrito por Álvaro Octavio de Toledo y Huerta, quien utiliza como fuente para su investigación cartas manuscritas redactadas por particulares a la Junta Suprema Central y Gubernativa del Reino (vigente desde septiembre de 1808 hasta su disolución en enero de 1810). Se continúa con tres artículos dedicados a cuestiones lingüísticas que, ora penetran, ora afloran en corpus hemerográficos españoles del siglo XIX: el primero, «Los textos periodísticos traducidos del francés (1830-1845): lengua y tradicionalidad», firmado por Elena Carmona Yanes; el segundo, «La utilidad de lo efímero en el estudio de la lengua del s. XIX: cuestiones gramaticales a través de la prensa», por Miguel Ángel Puche Lorenzo; y el tercero, «La prensa general y deportiva como fuente textual fundamental para la documentación de los primeros términos del fútbol en español (18681899)», por Antoni Nomdedeu Rull. Cierra el monográfico el artículo «Subjectivació i evidencialitat: el verb amenaçar fins al segle XIX. Un estudi de corpus», escrito por Jordi. M. Antolí Martínez, en el que examina la gramaticalización del verbo amenaçar en catalán desde sus orígenes hasta el siglo XIX, momento en el que los textos efímeros de diversa naturaleza (prensa, cartas, dietarios personales) canalizan los valores epistémico y evidencial del verbo. 
La relevancia del conjunto de cartas analizadas por Octavio de Toledo, a las que califica de «instantes» y sitúa en el «perfil concepcional "medio"» entre el polo de la máxima inmediatez y la máxima distancia comunicativas, radica en su doble condición de efímeras: de una parte, durante un tiempo muy breve - apenas un año - los españoles que vivían en los territorios no invadidos por los franceses pudieron escribir cartas a la Junta Suprema exponiendo sugerencias y opiniones para la expulsión de los franceses del territorio español; de otra parte, la prosa de las cartas es efímera por ser de elaboración rápida, es decir, no sujeta a una planificación previa, y por su consumo inmediato. El autor realiza una indagación amplia y minuciosa de los fenómenos morfosintácticos en las instancias y coteja su espacio de variación con el de la prosa culta del siglo XIX.

El análisis se estructura en tres secciones. Primeramente, se inquieren los fenómenos morfosintácticos condicionados por normas de prestigio, propios de la prosa culta: enclisis; laísmo y leísmo de objeto animado e inanimado; doblado de los sintagmas dativos posverbales de núcleo nominal (no pronominal); conectores adversativos (mas/pero) y cuantificadores exclamativos (cuán/qué); pronombres relativos (quien, el cual, que, el que) y anteposición del cuantificador negativo nada al verbo (nada sé) frente al esquema con concordancia negativa (no sé nada). A continuación, se examinan los fenómenos gramaticales en los que las misivas exhiben una situación de variación notoria distinta de la que muestra la prosa elaborada: formas verbales en $-r a$ y en -se en oraciones subordinadas no condicionales; hechos de morfología verbal (extensiones analógicas en temas de presente con vocal radical final); hechos que afectan a las oraciones completivas (uso del artículo, preposición...) y construcciones pasivas, mediopasivas e impersonales. El análisis se concluye con los fenómenos propios del «primer español moderno (h. 1675-1825)» que no arraigan en la prosa elaborada, pero sí, en la prosa media (por ejemplo, algunos aspectos de la nexuación), y con los que reflejan variación diatópica (doblado de objeto directo animado posverbal, infinitivos concertados, posesivos de tercera persona en entornos presentativos, $\mathrm{y}$ variación diastrática (naide).

El estudio arroja resultados reveladores sobre los fenómenos morfosintácticos usados en las cartas redactadas entre 1808 y 1809, que permiten, por un lado, ubicarlas en un perfil concepcional medio, en el que su espacio de variación es más amplio que el de la prosa culta, y por otro, acrecentar la caracterización morfosintáctica de las tradiciones discursivas epistolares y administrativas en estos primeros años del decimonónico.

El trabajo «Los textos periodísticos traducidos del francés (1830-1845): lengua y tradicionalidad» de Carmona Yanes saca a la luz uno de los temas lingüísticos que acaloraban la prensa del XIX: la influencia del francés y, más específicamente, las traducciones al español de textos periodísticos franceses publicados en las secciones de «Noticias extranjeras» o «Crónicas extrajeras» de la prensa española entre 1830 y 1845. Los quince años seleccionados coinciden con el final del «primer español moderno» y con el inicio de la época áurea del 
periodismo español; la combinación de estas dos circunstancias propicia que la autora dedique la introducción de su estudio a presentar el contexto en el que se enmarca la reelaboración de las fuentes extrajeras en la prensa.

Carmona Yanes se centra en la «materia lingüística» de las traducciones y la analiza desde la historia de la lengua y el análisis histórico del discurso. Para ello, se sirve del concepto de tradicionalidad discursiva y de la metodología que proporciona la lingüística de las variedades de raíz coseriana. La autora selecciona treinta artículos de nueve periódicos españoles y estudia la vigencia o consolidación de los elementos morfosintácticos más representativos de la época sujetos a la variación. Su pesquisa la lleva a diferenciar entre «interferencias positivas»e «interferencias negativas». En las primeras, incluye elementos que tienen influencia directa del texto francés: temas, formatos, moldes textuales y, sobre todo, los hechos que afectan al ámbito microlingüístico, nominados galicismos gramaticales crudos (abundancia de pronombres sujeto, empleo de la preposición de para introducir oraciones infinitivas...). En las segundas, las «interferencias negativas», se adentra en tres recursos gramaticales susceptibles a la variación lingüística en el español del primer tercio del siglo XIX, y que en francés eran estables: las soluciones que se dan en la prensa española de la marcación preposicional (a) de algunos tipos de complementos directos, los empleos oblicuos del relativo (que, el que, el cual) y el uso del artículo definido ante nombres propios de países o continentes («la España», «la Europa»).

Las conclusiones a las que Carmona Yanes llega sorprenderían a quienes criticaban y parodiaban la influencia del francés sobre el español en la prensa.

El segundo de los artículos que utiliza como fuente documental los corpus hemerográficos es «La utilidad de lo efímero en el estudio de la lengua del s. XIX: cuestiones gramaticales a través de la prensa», firmado por Miguel Ángel Puche Lorenzo. Esta contribución podría considerarse una crónica de los intereses lingüísticos de la época, pues en ella se expone una relación de las cuestiones gramaticales que se difunden a través de los periódicos entre los años 1833 y 1868, es decir, durante el reinado de Isabel II.

El estudio se inicia con la exposición de las causas por las que la prensa se convirtió en el medio privilegiado para mostrar y difundir temas lingüísticos y se ilustra con las palabras pronunciadas por Juan Francisco Pacheco y Eugenio Sellés en sus discursos de ingreso en la Real Academia. Ambos discursos evidencian la condición efímera de la prensa, con sus ventajas y desventajas, presagiando - evidentemente sin pretenderlo - lo efímero de las escrituras digitales del momento que nos ha tocado vivir (el siglo XXI).

Puche Lorenzo focaliza la atención en todos los elementos que confluyen cuando la lengua se convierte en la noticia: los lugares que ocupa en el periódico; las secciones en las que se incluye; los temas de lengua tratados y las diferentes perspectivas desde las que son abordados; las actitudes y críticas ante lo emanado desde la Academia (a este respecto, como expone el autor, son muy reveladores los comentarios lingüísticos y las reacciones que suscitaron los 
discursos de ingreso en la docta institución de Eugenio Ochoa, Antonio Soler y Javier Quinto); la influencia de la lengua francesa sobre la española y las noticias laudatorias y reprobatorias dedicadas a las gramáticas publicadas y utilizadas en aquellos años para la enseñanza en las escuelas y universidades. El autor insiste en la siguiente idea: la prensa fue el medio para introducir «nuevas aportaciones gramaticales» y para difundir de forma inmediata propuestas teóricas y de uso sobre preposiciones, locuciones, sinónimos, etimologías, galicismos, anglicismos... Puche Lorenzo no se olvida de los comentarios que algunas construcciones («Hacer el oso», «A los pies de $\mathrm{Vd}$.» o «Beso a Vd. la mano») despertaron en los lectores y redactores de la prensa. También dedica un espacio a los artículos que no tienen la lengua como eje de la noticia, pero que en los que se localizan estructuras que se generalizaron en el siglo XIX, como, por ejemplo, «una salida de cajón» o «por lo bajo» con verba dicendi.

El autor acompaña el análisis con una minuciosa selección de fragmentos extraídos de veintidós periódicos, que constatan la relevancia de la prensa para reconstruir y conocer «el pasado lingüístico del español», a pesar de su condición efímera.

El artículo de Nomdedeu, «La prensa general y deportiva como fuente textual fundamental para la documentación de los primeros términos del fútbol en español (1868-1899)», nos traslada a los inicios léxicos - permítaseme la expresión - de un deporte que desde hace ya algunos años se ha convertido en el gran preferido - permítaseme también esta expresión-, si se tiene en cuenta su número seguidores.

Este trabajo ofrece una descripción diacrónica del léxico del fútbol en un corpus periodístico español publicado entre 1868 y 1899, enriquecido con otras fuentes textuales y de coleccionismo privado. El recorrido histórico que se realiza no deja indiferente al lector, sea aficionado o no a ese deporte. El estudio forma parte de una investigación sobre historiografía del léxico del fútbol español, concretamente, del Diccionario Histórico de Términos del Fútbol (DHTF). En este lugar, el autor se centra en el período llamado «inicios de la prensa deportiva y creación de un espacio propio» (1868-1899), momento en el que documenta los primeros términos futbolísticos en español.

Nomdedeu explica de forma sistemática cuál ha sido la metodología empleada para la creación del corpus de trabajo, formado por 206 obras, y determina que para el período inicial (1868-1899) son catorce los textos en los que poder extraer términos futbolísticos, en su mayoría, incluidos en los periódicos La Vanguardia y Los Deportes. La búsqueda léxica realizada por el autor arroja cincuenta y cinco términos en español: botar ('sacar'), castillo ('portería'), defensor en puerta ('portero'), corredor ('futbolista'), entrada ('gol'), etc., que evidencian que en esos años el fútbol comenzaba a ser noticia, aunque el espacio que ocupaba en la prensa todavía era reducido, en comparación con el dedicado a otras prácticas deportivas (caza, ciclismo, equitación, esgrima o tenis). De los cincuenta y cinco términos, ocho son extranjerismos (siete anglicismos y un italianismo), pero, 
como la historia de este deporte ha confirmado, fue a partir de 1900 cuando los anglicismos «poblaron» la prensa futbolística, llegando, incluso, a ser motivo de debate lingüístico la castellanización de los anglicismos deportivos en la prensa española durante los primeros años del siglo XX con artículos tan significativos como: «No se dice foot-bal, dígase balompié» o «Filología deportiva».

Una de las consecuencias de la búsqueda de términos futbolísticos en el corpus es el descubrimiento de fechas y acontecimientos relevantes en los inicios de la prensa deportiva: (i) 30 de abril de 1868, primera referencia al fútbol en el artículo «El foot-ball (bola de pie) en Inglaterra», publicado en el período El panorama, Periódico ilustrado quincenal (Valencia); (ii) 12 de marzo de 1890, primera crónica de un partido de fútbol en La Provincia (Huelva), donde el léxico hace referencia al desarrollo del juego, las acciones y las demarcaciones; y (iii) 24 de diciembre de 1899, inicio de la primera sección dedicada en exclusiva al fútbol («Foot-ball») en Los deportes, que marcará el comienzo del período de esplendor de este deporte en la prensa.

El estudio de Nomdedeu demuestra que los términos futbolísticos españoles surgen y se consolidan en la prensa y que el fútbol es uno de los ámbitos que «mayor innovación léxica» ha tenido desde los años 70 del siglo XIX.

Concluimos esta descripción con el artículo «Subjectivació i evidencialitat: el verb amenaçar fins al segle XIX. Un estudi de corpus», de Jordi. M. Antolí Martínez. Con una perspectiva diacrónica, expone y analiza el proceso de cambio sintáctico y semántico que el verbo amenaçar experimentó en catalán desde su valor originario agentivo (expresión de una amenaza) hasta su valor epistémico/evidencial (subjetivo) a partir del segundo tercio siglo XIX. Este proceso es compartido con otras lenguas románicas (aragonés, asturiano, español, francés italiano y occitano). En este sentido, la investigación de Antolí va en paralelo con los planteamientos que para el español (amanazar) expusieron Cornillie $(2007,2016)$ y Cornillie y Octavio de Toledo (2015); para el inglés (threaten), Traugott $(1993,1997)$ y para los verbos que expresan el concepto 'amenazar' en las lenguas europeas, Heine y Kuteva (2006).

Antolí realiza un exhaustivo trabajo con tres corpus lingüísticos de la lengua catalana: Corpus Informatitzat de la Gramàtica del Català Antic (CIGCA), Corpus Informatitzat de la Gramàtica del Català Modern (CIGCMod) y Corpus Textual Informatitzat de la Llengua Catalana (CTILC), que, en su conjunto, abarcan desde los primeros textos conservados, fechados en la primera mitad del siglo XIII, hasta finales del siglo XX. La indagación en los corpus lleva al autor a analizar cualitativa y cuantitativamente 672 casos del verbo amenaçar con los presupuestos teóricos y metodológicos que proporcionan la Lingüística Cognitiva, la Gramática de Construcciones basada en el uso (Traugott y Trousdle 2013), la Invited Inferencing Theory of Semantic Change (Traugott 2012) y el concepto de subjetivación (Traugott y Dasher 2002).

El análisis de los resultados revela que amenaçar ha tenido ocho significados en diacronía, que configuran las tres fases de su evolución, coincidentes con las 
etapas de evolución de la lengua catalana: (i) s. XIII-s. XVI, (ii) s. XVII-1832 y (iii) 1833-1903. El autor, a través del análisis de las estructuras semánticas y sintácticas del verbo en las tres fases, observa un progresivo proceso de subjetivación en el que se van desplegando los valores epistémicos y evidenciales en textos del siglo XIX proclives a la expresión personal del autor y a una mayor subjetividad (correspondencia, prensa, textos historiográficos y dietarios personales). Es en estos textos, en general de carácter efímero, en los que Antolí encuentra la interferencia entre el verbo español (amenazar) y el catalán (amenaçar).

Nuestra intención con este monográfico ha sido dar un paso más en el conocimiento de la lengua del XIX mostrando que las escrituras y los textos pasajeros del siglo XIX son - utilizo las palabras escritas por Puche Lorenzo en su contribución- «parte de nuestro pasado lingüístico» y uno de sus exponentes documentales. Esperamos haberlo conseguido.

Finalizo la presentación de este monográfico haciendo uso del refrán español Es de bien nacidos ser agradecidos, por eso quiero mostrar mi gratitud a los cinco autores firmantes de los artículos, por su participación; a los diez evaluadores externos, por su disposición y celeridad, y a la directora de la revista, Mar Garachana, por aceptar la propuesta que le hicimos en la primavera de 2018.

\section{BIBLIOGRAFÍA}

AlezA IZQUiERDO, M. y ENGUITA UtRILlA, J. M. (coords.) (2010), La lengua española en América: normas y usos actuales, Valencia, Universitat de València.

ANDREO GARCÍA, J. (1999a), «Entre la ficción romántica y la realidad histórica. La "imagen" de Cuba a través del grabado y la pintura colonial; claves para su utilización como fuente historiográfica», en Imágenes e imaginarios nacionales en el ultramar español, Naranjo, C. y Serrano, C. (eds.), Madrid, CSIC, Casa de Velázquez, 369-391.

ANDREO GARCÍA, J. (1999b), «Sobre la construcción del imaginario: la mulata en la litografía cubana del XIX. Una propuesta de interpretación», en Ser mujer y tomar la palabra en América Latina: Pensar y escribir, obrar y reaccionar, Andreo, J. y Forgues, R. (eds.), Murcia-Pau, Universidad de Murcia-Presses Universitaires de Pou, 3961.

ANDREO GARCíA, J. (1999c), «Sobre la construcción social de la imagen femenina: la mulata en la litografía cubana del XIX», en Mujer, creación y problemas de identidad en América Latina, Forgues, R. (comp.), Mérida, Universidad Los Andes, Consejo de Publicaciones, 33-53.

ANDREO GARCÍA, J. (2013), «No hay tamarindo dulce ni mulata señorita. La construcción de identidades de raza y género en la Cuba de finales del período colonial», en Afroamérica, espacios e identidades, Laviña, J., Piqueras, R. y Mondéjar, C. (eds.), Barcelona, Icaria, 181-202.

ANDREO GARCíA, J. y GULLÓN ABAO, A. J. (1997), «’Vida y muerte de la Mulata'. Crónica ilustrada de la prostitución en la Cuba del XIX», Anuario de Estudios Americanos, 54(1), 135-157. 
ARAMBURU, D. (2010), «Las fiestas afrocubanas en las marquillas cigarreras del siglo XIX: el "Almanaque profético para el año 1866"», Afro-Hispanic Review, 29(1), 11-34.

BELIN, O. (2015), «La presse lycéenne, permanences d'un média éphémère», Fabula. Les colloques. Les éphémères, un patrimoine à construire, 1-6. Disponible en: $<$ http://www.fabula.org/colloques/document2914.php>.

BELIN, O. y FERRAN, F. (2016), «Les éphémères, un continent à explorer», Fabula. Les colloques. Les éphémères, un patrimoine à construire, 1-12. Disponible en: $<$ http://www.fabula.org/colloques/document3097.php>.

BOTREL, J.-F. (2013), «Ardientes mujeres: escritoras y poetisas en cajas de cerillas», en $\mathrm{La}$ otra Edad de Plata. Temas, géneros y creadores (1898-1936), Ena, Á. (ed.), Madrid, Editorial Universidad Complutense, 21-47.

BOTREL, J.-F. (2016a), «Ephemera \& non libres en Espagne: statud \& patrimonialisation», Fabula. Les éphémères, un patrimoine à construire, 1-12. Disponible en: $<$ https://www.fabula.org/colloques/document2938.php>.

BOTREL, J.-F. (2016b), «Pour les ephemera, des nomenclatures sans frontières?», Fabula. Les colloques. Les éphémères, un patrimoine à construire, 1-2. Disponible en: $<$ http://www.fabula.org/colloques/document2941.php>.

Bustos TOVAR, J. J. (1996), «La imbricación de la oralidad en la escritura como técnica del discurso narrativo», en El español hablado y la cultura oral en España e Hispanoamérica, Kotschi, Th., Oesterreicher, W. y Zimmermann., K. (eds.), Frankfurt-Madrid, Vervuert-Iberoamericana, 359-374.

BUZEK I. Y SINKOVÁ M. (eds.) (2015a), Una cercana diacronía opaca: Estudios sobre el español del siglo XIX, Études Romanes de Brno, 36(1).

BUZEK I. Y STINKOVÁ M. (eds.) (2015b), Una cercana diacronía opaca: Estudios sobre el español del siglo XIX, Études Romanes de Brno, 36(2).

CAlZAdilla, Y. (2018), «La Honradez, museo de artes y manufacturas», Opus Habana, XVII (3), 22-31.

CÁMARA, M. (2003), «Ochún en la cultura cubana: metáfora y metonimia en el discurso de la nación», La Palabra y el Hombre, Revista de la Universidad Veracruzana, 125, 2134 .

CARo BARoja, J. (1990), Ensayo sobre la Literatura de Cordel, Madrid, Ediciones Istmo.

CARPI, E. Y GARCÍA JIMÉNEZ, R. M. (eds.) (2017), Herencia e innovación en el español del siglo XIX, Pisa, University Press.

CASTELlANOS, J. y CASTELlANOS, I. (1992), Cultura afrocubana, 3. Las religiones y las lenguas, Miami, Ediciones Universal.

CAstillo GómeZ, A. (2005), «'El mejor retrato de cada uno'. La materialidad de la escritura epistolar en la sociedad hispana de los siglos XVI y XVII», Hispania, 65(221), 847-876.

CAstillo GómeZ, A. (2013), «Mensajes efímeros. Escribir billetes en el Siglo de Oro hispánico», en Cartas - Lettres - Lettere. Discursos, prácticas y representaciones epistolares (siglos XIV-XX), Castillo, A. y Sierra, V. (dirs.), Alcalá de Henares, Universidad de Alcalá, 365-389.

$C D H=$ INSTITUTO DE INVESTIGACIÓN RAFAEL LAPESA DE LA REAL ACADEMIA ESPAÑOLA. Corpus del Nuevo diccionario histórico [en línea]. Madrid: 2013 [Consulta: 18 septiembre 2019]. Disponible en <http://web.frl.es/CNDHE>.

Clinton, A. (1981), Printed ephemera. Collection, organisation and access, London, Clive Bingley. 
COMPANY COMPANY C. (dir.) (2006), Sintaxis histórica de la lengua española. Primera parte: La frase verbal, México, UNAM y FCE.

COMPANY COMPANY C. (dir.) (2009), Sintaxis histórica de la lengua española. Segunda parte: La frase nominal, México, UNAM y FCE.

COMPANY COMPANY, C. (2012), «El español del siglo XVIII. Un parteaguas lingüístico entre México y España», en El español del siglo XVIII. Cambios diacrónicos en el primer español moderno, García-Godoy, Ma T. (ed.), Bern, Peter Lang, 255-291.

COMPANY COMPANY C. (dir.) (2014), Sintaxis histórica de la lengua española. Tercera parte: Adverbios, preposiciones y conjunciones. Relaciones interoracionales, México, UNAM y FCE.

COMPANY COMPANY, C. Y FlORES DÁviLA, R. (2017), "Género textual, diacronía y valoración de un cambio sintáctico. A por con verbos de movimiento», $B R A E$, 97(315), 203-239.

DE JuAN, A. (1974), Pintura y grabado coloniales cubanos: contribución a su estudio, La Habana, Editorial Pueblo y Educación.

DE JUAN, A. (1977), «El negro en la pintura cubana del siglo XIX», Revista de la Universidad de México, 2, 13-17.

De JUAN, A. (1980), Pintura cubana: temas y variaciones, México D.F., UNAM.

DLE = REAL ACADEMIA ESPAÑOLA y ASOCIACIÓN DE ACADEMIAS DE LA LENGUA ESPAÑOlA. Diccionario de la lengua española [en línea], versión electrónica 23.2. Madrid: 2014, 2018 [Consulta: 10 septiembre 2019]. Disponible en: $<$ http://dle.rae.es/?w=diccionario $>$.

Domínguez HernándeZ, M. A. (ed.) (2007), La lengua en Cuba. Estudios, Santiago de Compostela, Universidad de Santiago de Compostela.

DOMÍNGUEZ HERNÁNDEZ, M. A. (2012), «Para una caracterización de la variedad cubana del español en la década del cuarenta decimonónica. Comentario de cartas», Normas. Revista de Estudios Lingüísticos Hispánicos, 2, 47-62.

DRAE = REAL ACADEMIA ESPAÑOLA. Diccionario de la lengua castellana compuesto por la Real Academia Española, reducido á un tomo para su mas fácil uso [en línea]. Madrid: Viuda de don Joaquín Ibarra, $1791^{3}$ [Consulta: 7 de julio 2019]. Disponible en: Nuevo Tesoro Lexicográfico de la lengua española (NTLLE) $<$ http://ntlle.rae.es/ntlle/SrvltGUILoginNtlle>.

FRAUNHAR, A. (2008), «Marquillas cigarreras cubanas: Nation and Desire in the Nineteenth Century», Hispanic Research Journal, 9(5), 458-478.

GARACHANA, M. (ed.) (2017), La gramática en la diacronía. La evolución de las perífrasis modales en español, Frankfurt am Main, Iberoamericana Vervuert.

GiMÉNEZ CABALlERO, F. (2013), «Marquillas cigarreras», Herencia Cultural Cubana, 19(1), 32-35. Disponible en: <https://issuu.com/herenciaculturalcubana/docs/19.1_ march_2013>.

GOMIs COlOMA, J. (2015), Menudencias de imprenta. Producción y circulación de la literatura popular (Valencia, siglo XVIII), Valencia, Institució Alfons el Magnánim.

GONZÁlEZ DEL VALLE, F. (1947), La Habana en 1841. Obra póstuma ordenada y revisada por R. Catalá, La Habana, Municipio de la Habana.

GRAND-CARTERET, J. (1896), Vieux papiers, vieilles images: cartons d'un collectionneur, Paris, Chez A. Le Vasseur et Cie.

GRANDA, G. de (1971), "Algunos datos sobre la pervivencia del "criollo" en Cuba», BRAE, 51(194), 481-492. 
HAZARD, S. (1928), Cuba a pluma y lápiz. «La siempre fiel isla», tomo 1, Habana, Cultural. ISBĂŞESCU, C. (1968), El Español en Cuba. Observaciones fonéticas y fonológicas, Bucarest, Sociedad Rumana de Lingüística Románica.

KUTZINSKI, V. M. (1993), Sugar's Secrets, Race and the Erotics of Cuban Nationalism, Charlottesville, University Press of Virginia.

LAKOFF, (1987), Women, Fire, and Dangerous Things. What Categories Reveal about the Mind. Chicago, The University of Chicago Press.

LAPIQUE BECALI, Z. (1999), «Los sucesos de la historia de España y Cuba en las etiquetas de los cigarrillos y Habanos cubanos», en Imágenes e imaginarios nacionales en el ultramar español, Naranjo, C. y Serrano, C. (eds.), Madrid, CSIC, Casa de Velázquez, 103-116.

LEWIS, J. (1962), Printed ephemera: the changing uses of type and letterforms in English and American printing, Ipswich, W. S. Cowell.

LEWIS, J. (1976), Collecting printed ephemera: a background to social habits and social history, to eating and drinking, to travel and heritage and just for fun, London, Studio Vista.

LÓPEZ MORALES, H. (1980), "Sobre la pretendida existencia y pervivencia del "criollo" cubano», Anuario de Letras: Lingüística y filología, 18, 85-116.

LÓPEZ MORALES, H. (1992), El español del Caribe, Madrid, Editorial Mapfre.

LÓPEZ Morales, H. (2018), Estudios sobre el español de Cuba, Madrid, Ensayo Verbum.

LuGO ORTIZ, (2012), «Material Culture, Slavery, and Gobernability in Colonial Cuba: The Humorous Lessons of the Cigarette Marquillas», Journal of Latin American Cultural Studies, 21(1), 61-85.

MCDOWELL, P. (2012), «Of Grubs and Other Insects. Constructing the Categories of 'Ephemera' and 'Literature' in Eighteenth-Century British Writing», Book History, 15, 31-53.

MAKEPEACE, CH. E. (1985), Ephemera: A book on its collection, conservation and use, Aldershot, Gower.

MANCERA RUEDA, (2009), «La oralidad 'simulada' en la narrativa contemporánea», Verba: Anuario Galego de Filoloxia, 36, 419-436.

Martínez GonZÁlez, J. Ma y Freire SANTA CRUZ, R. J. (eds.) (2018), LIJ Efímera. La perfecta imperfección de los no libros, Cuenca, Ediciones de la Universidad de CastillaLa Mancha.

MedranO, F. (1999), "Ni chicha ni limonada": Depictions of the Mulatto Woman in Cuban Tobacco Art». Research Paper Series, 34, Albunquerque, New Mexico, Latin American and Iberian Institute, University of New Mexico, 1-36.

MÉGEVAND, S. (2018), «La alquimia íntima de las raíces. Consideraciones estéticas e identitarias sobre la litografía decimonónica cubana de origen europeo», en Caribe hispano y Europa. Siglos XIX y XX. Dos siglos de relaciones, Opatrný, J. (coord.), PragaUniversidad Carolina, Editorial Karolinum, 139-148.

Melis, CH., FloRES, M. y BOGARD, S. (2003), «La historia del español. Propuesta de un tercer periodo evolutivo», Nueva Revista de Filología Hispánica, 51(1), 1-56.

MELIS, CH. y FLORES, M. (eds.), El siglo XIX. Inicio de la tercera etapa evolutiva del español, México, UNAM, Instituto de Investigaciones Filológicas.

MÉNDEZ GÓMEZ, S. (2015), «Feminidades racializadas e imaginarios coloniales en el humor gráfico de Cuba en el s. XIX», Revista Científica de Información y Comunicación, $12,135-170$. 
MENNESSIER, A.-L. (2005), Le traitement des éphémères en bibliothèque: l'exemple de la collection Arthur Labbé de la Mauvinière à la médiathèque François - Mitterrand de Poitiers, Mémoire d'étude, École National Supérieure des Sciences de l'Information et des Bibliothèques.

MiLlÁN, J. A. (1852), «El maestro de escuela», en Los cubanos pintados por si mismos. Colección de tipos Cubanos, VV.AA, tomo 1, Habana, Imprenta y papelería de Barcina, 275-288.

MONTORI Y CÉSPEDES, A. (1916), «Modificaciones populares del idioma castellano en Cuba», Cuba contemporánea, 11, La Habana, Impr. De “Cuba pedagógica”, 232-252.

MONTORO DEL ARCO, E. T. (2012), «Fraseología y paremiología», en Reflexión lingüística y lengua en la España del XIX. Marcos, panoramas y nuevas aportaciones, Zamorano, A. (ed. y coord.) Muenchen, Limcom Studies in Romance Linguistics, 173-196.

MORENO FERNÁNDEZ, F. (2006), «Lengua e historia. Sociolingüística del español desde 1700», en Estudios sociolingüísticos del español de España y América, Cestero, A. M., Molina, I. y Paredes, F. (eds.), Madrid, Arco/Libros, 81-96.

Octavio De TOledo y HuerTA Á. S., Y PONS RODRíGueZ L. (2016), Queja política y escritura epistolar durante la Guerra de Independencia: documentación de la Suprema Junta Central en el AHN, Selección, edición y estudio lingüístico, Alcalá de Henares, Universidad de Alcalá.

OESTERREICHER, W. (1996), «Lo hablado en lo escrito. Reflexiones metodológicas y aproximación a una tipología», en El español hablado y la cultura oral en España e Hispanoamérica, Kotschi, Th., Oesterreicher, W. y Zimmermann., K. (eds.), Frankfurt-Madrid, Vervuert-Iberoamericana, 317-340.

OESTERREICHER, W. (2004), «Textos entre inmediatez y distancia comunicativas. El problema de lo hablado escrito en el Siglo de Oro», en Historia de la lengua española, Cano, R. (coord.), Barcelona, Ariel, 729-769.

OrTIZ, F. (1923), Un catauro de cubanismos. Apuntes lexicográficos, Habana, Calle L. Esquina A 27a.

ORTIZ, F. (1924), Glosario de Afronegrismos, Habana, Imprenta «El Siglo XX».

OrTIZ, F. (1999 [1940]), Contrapunteo cubano del tabaco y del azúcar, Madrid, Edito Cuba España.

ORTIZ GARCÍA, C. (2000), «Papeles para un pueblo. Hojas sueltas y otros impresos de consumo masivo en la España de finales del siglo XIX», en Palabras para el pueblo. Aproximación general a la literatura de Cordel, Díaz, L. y Godino, A (eds.), vol. 1, Madrid, CSIC, 145-190.

PADILLA, X. (2019), «Humor y comunicación multimodal: las viñetas cómicas», en Guía práctica de pragmática del español, Placencia, Maㅡ E. y Padilla, X. (eds.), London, Routledge, 160-170.

Pemberton, J. E. (1971), The National Provision of Printed Ephemera in the Social Sciences, Coventry, University of Warwick Library.

PICHARDO Y TAPIA, E. $\left(1862^{3}\right)$, Diccionario provincial casi-razonado de vozes cubanas, La Habana, Imprenta La Antilla.

PROVENCIO GARRIGÓs, H. (en prensa), Las marquillas cigarreras cubanas (1850-1900). Estudio lingüístico y discursivo.

RAE-ASALE (2009), Nueva gramática de la lengua española, Madrid, Espasa Libros.

RAmírez Luengo, J. L. (2007), Breve historia del español de América, Madrid, Arco/Libros. 
RAmíRez Luengo, J. L. (ed.) (2012), Por sendas ignoradas. Estudios sobre la lengua española en el siglo XIX, Lugo, Axac.

RAMOS PÉREZ, R. (2003), Ephemera. La vida sobre el papel. Colección de la Biblioteca Nacional, Madrid, Biblioteca Nacional.

RichardS, M. (1977), This is Ephemera. Collecting Printed Throwaways, Brattleboro, Gossamer Press.

RICHARDS, M. (2000), The Encyclopedia of ephemera: a guide to the fragmentary documents of everyday life for the collector, curator and historian, London, The British Library.

Rodríguez LeHMANN, C. y BOUZAGIO, N. (coords.) (2018), Miradas efímeras. Cultura visual en el siglo XIX, Santiago, Editorial Cuarto Propio.

RuedA RAMírez, P. J. (2014), «Impresos efímeros en la vida cotidiana. Carteles, calendarios, coplas y relaciones», Andalucía en la historia. Dossier Vivir en el Siglo de Oro, 44, 36-38.

SALVÁ, V. (1846), Nuevo diccionario de la lengua castellana, que comprende la última edición integra, muy rectificada y mejorada del publicado por la Academia Española, y unas veinte y seis mil voces, acepciones, frases y locuciones..., Paris, Librería de Don Vicente Salvá. Disponible en: Nuevo Tesoro Lexicográfico de la lengua española (NTLLE), $<$ http://ntlle.rae.es/ntlle/SrvltGUILoginNtlle>.

SÁNCHEZ BUSTAMANTE Y PARAJÓN, A. (2013), «La mulata en las marquillas del siglo», Herencia Cultural Cubana, 19(2), 40-43. Disponible en: $<$ https://issuu.com/herenciaculturalcubana/docs/19.2_october_2013>.

SÁNCHEZ RoIG, M. (1966), "Notas inéditas sobre el grabado en Cuba», Revista de la Biblioteca Nacional "José Martí", 57(1), 1-44.

SEPÚlvedA, A. (2015), «Humor and Social Hygiene in Havana's Nineteenth-Century Cigarette Marquillas», Nineteenth-Century Art Worldwide, 14(3), 56-83. Disponible en: <http://www.19thc-artworldwide.org/autumn15/sepulveda-on-havana-19thcentury-cigarette-marquillas $>$.

SOLÉ BOLADERAS, I. (2017), «Ephemera o el calaix de sastre: accessibilitat i visibilitat més enllà de les definicions», Item: Revista de Biblioteconomia i Documentació, 63, 135-154.

ŠTRBÁKOVÁ, R. (2013), La dinámica del léxico de la moda en el siglo XIX: estudio de neología léxica, Bucureşti, Editura Universităţii din Bucureşti.

SuÁreZ, C. (1921), Vocabulario Cubano. Suplemento a la 14. ${ }^{a}$ edición del Diccionario de la $R$. A. de la Lengua, Madrid-La Habana, Librería de Perlado-Páez y Cía-Librería Cervantes de Ricardo Veloso.

TERREROS Y PANDO, E. DE (1767), Diccionario castellano con las voces de ciencias y artes y sus correspondientes en las tres lenguas francesa, latina e italiana, 4 vols., Madrid, Viuda de Ibarra.

TRENC BALLESTER, E. (1977), Les arts gràfiques de l'època modernista a Barcelona, Barcelona, Gremi d'Indústries Gràfiques.

TRENC BALlESTER, E. (2004), «El modernismo en las artes gráficas en España, particularmente en Aragón», Argensola: Revista de Ciencias Sociales del Instituto de Estudios Altoaragoneses, 114, 63-86.

TRISTÁ PÉREZ, A. Ma y CÁRDENAS MOLINA, G. (2016), Diccionario ejemplificado del español de Cuba, tomo 2, La Habana, Instituto de Literatura y Lingüística, Instituto Cubano del Libro, Editorial de Ciencias Sociales.

VAQUERO DE RAMíREZ, M. (1996), «Antillas», en Manual de dialectología hispánica. El español de América, Alvar, M. (dir.), Barcelona, Ariel, 51-67. 
VAQUERO DE RAMíREZ, M. (2006), «La formación de las grandes zonas dialectales del español de América», en Actas del VI Congreso Internacional de Historia de la Lengua Española, Bustos, J. J. y Girón, J. L., (eds.), vol. 1, Madrid, Arco/Libros, 185-215.

WiNTER-FroemEL, E., LÓPEZ SERENA, A., OCTAVIO dE TOLEDO Y HUERTA, Á. Y FrANK-JOB, B. (eds.) (2015), Diskurstraditionelles und Einzelsprachliches im Sprachwandel I Tradicionalidad discursiva e idiomaticidad en los procesos de cambio lingüistico, Tübingen, Gunter Narr.

ZAMORANO AgUiLAR, A. (ed. y coord.) (2012), Reflexión lingüística y lengua en la España del XIX. Marcos, panoramas y nuevas aportaciones, Muenchen, Limcom Studies in Romance Linguistics. 